\title{
DESIGNING SAFER
}

LIVELIHOODS

PROGRAMMES FOR

WOMEN SURVIVORS OF

GENDER-BASED

VIOLENCE IN GAZA

\section{EMILY FARR}

\section{EMERGENCY FOOD SECURITY AND VULNERABLE LIVELIHOODS ADVISOR, OXFAM}

Humanitarian agencies can unintentionally increase risks associated with livelihoods activities, including the risk of Gender-Based Violence (GBV). This study captures the risks and risk mitigation strategies related to livelihoods support in the Gaza Strip as identified by women survivors of GBV, adolescent girls, and adolescent boys. Through the results of this research, Oxfam and other humanitarian actors can better understand current and potential risks resulting from women's livelihoods activities in Gaza and can use the results to inform the design of safer programming.

Oxfam Research Reports are written to share research results, to contribute to public debate and to invite feedback on development and humanitarian policy and practice. They do not necessarily reflect Oxfam policy positions. The views expressed are those of the author and not necessarily those of Oxfam.

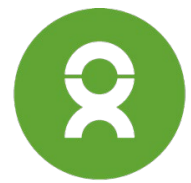




\section{CONTENTS}

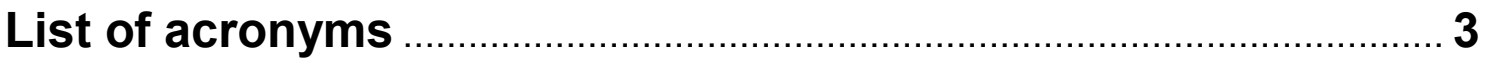

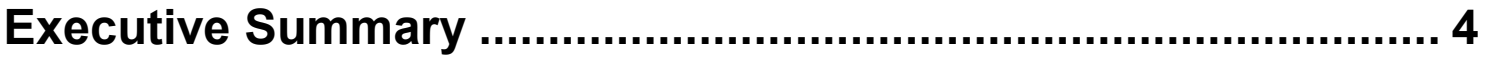

1 Introduction ....................................................................... 6

2. Gaza context ........................................................................ 7

3. Methodology ....................................................................... 9

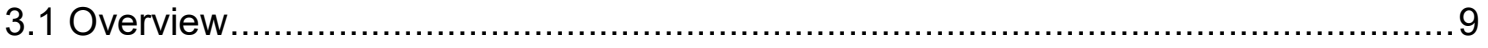

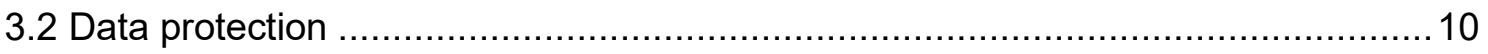

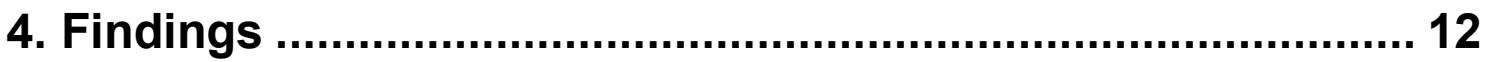

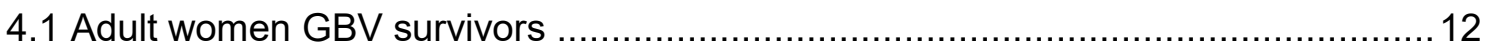

4.1.1 Livelihoods activities and impacts of the Gaza crisis ................................... 12

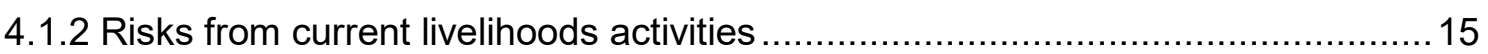

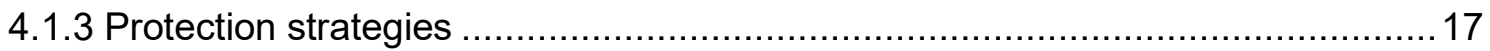

4.1.4 New or improved livelihoods opportunities for women and support needed ....... 18

4.1.5 Threats and risks from new livelihoods opportunities for women .......................20

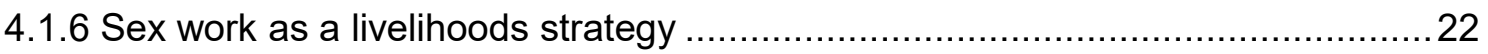

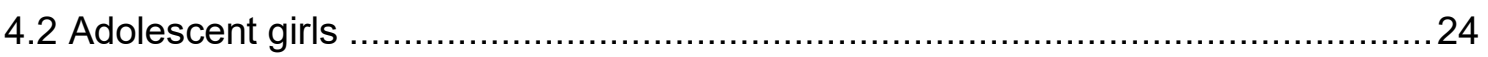

4.2.1 Adolescent girls' participation in livelihoods and the impact on their education .. 24

4.2.2 Livelihoods opportunities for adolescent girls and support needed.................... 25

4.2.3 Threats and risks from new livelihoods opportunities for adolescent girls ...........26

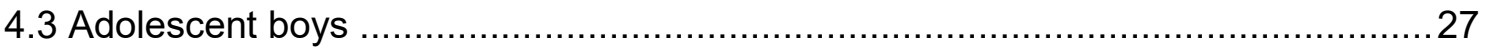

4.3.1 Adolescent boys' participation in livelihoods and the impact on their education 27

4.3.2 Livelihoods opportunities for adolescent boys and support needed...................28

4.3.3 Threats and risks from new livelihoods opportunities for adolescent boys .......... 29

5. Recommendations - prevention and mitigation strategies.. 31

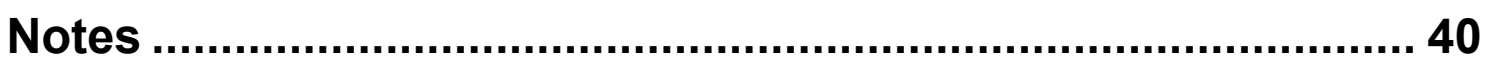

Acknowledgements .............................................................. 41

Annex: Questionnaire .......................................................... 42 


\section{LIST OF ACRONYMS}

- CLARA Cohort Livelihoods and Risk Analysis

- FGD Focus group discussion

- GBV Gender-based violence

- $\mathrm{HH} \quad$ Household

- IPV Intimate partner violence

- ILS Israeli new shekels

- MEAL Monitoring, evaluation, accountability and learning

- OPT Occupied Palestinian Territory

- PA Palestinian Authority

- SefSec Socio-Economic and Food Security Survey

- UNRWA United Nations Relief and Works Agency 


\section{EXECUTIVE SUMMARY}

Livelihoods are an essential way for crisis-affected people to cope with and recover from shocks. However, humanitarian activities can unintentionally increase risks associated with livelihoods activities, including the risk of Gender-Based Violence (GBV). Gender risk analysis can inform programme design so that safe livelihoods initiatives can be supported by humanitarian actors.

In March and April 2019, Oxfam conducted a Cohort Livelihoods and Risk Analysis (CLARA) in the Gaza Strip in the Occupied Palestinian Territory (OPT). The CLARA study in Gaza is primarily intended to inform Oxfam's understanding of the gender risks associated with livelihoods, risk mitigation and prevention strategies, and the needs and opportunities of women who are survivors of GBV in Gaza. Interviews were conducted with 70 women who are survivors of GBV, and additional focus groups were held with adolescent girls and boys from the women's households.

The analysis found that women's livelihoods have been severely impacted by the current crisis in Gaza1. Almost $76 \%$ of women reported that their livelihood or the livelihood of a spouse or family member has been affected by specific shocks within the Gaza context. Among those who reported that their livelihood has been affected, the majority said the primary impact is from the Palestinian Authority (PA) restrictions in 2017. The most prevalent way that the women survivors of GBV interviewed meet their basic needs and access money is through support from others, including food assistance, support from relatives or charity. Women interviewed practice a range of livelihoods activities; these are mostly highly gendered strategies based around activities that are typically done by women, as these are more permissible in the context.

Women survivors of GBV interviewed said that their livelihoods activities are often risky, and this risk has increased significantly as a result of shocks in the context and the Gaza crisis. Some $39 \%$ of women interviewed said that their current livelihoods activities make them feel vulnerable or unsafe. By contrast, only $7 \%$ of the women said that their livelihoods activities were unsafe before the crisis in Gaza. The primary threat women said they experience now is due to economic vulnerability - the effects of being unable to meet basic needs of the household due to low wages and limited income opportunities. They live on charity and debt, can't find income opportunities, and fear falling into further destitution.

Women feel at greater risk of GBV or other harm due to their current livelihoods strategies, for reasons including working in male-dominated spaces like markets, having to walk long distances or spend long periods outside selling goods, or working in private homes. They also feel vulnerable due to humiliation and loss of dignity caused by their food security and livelihoods strategies. Women reported experiencing humiliation in part because they have had to take on responsibilities to provide for themselves and their families, and in part because the strategies they have to use to get food or income are not considered decent or respectable. Women also said they experience intimate partner violence (IPV) due to their economic situation, which some linked to stress around survival and providing for the family.

The women survivors of GBV proposed a range of activities to improve their own livelihoods and income. Women are particularly interested in starting market-based businesses, particularly related to sewing, embroidery, crochet or dressmaking. Other popular areas of interest are in education and childcare, opening grocery stores or produce stands, and starting or expanding businesses to make and sell cleaning products. In order to start or expand their livelihoods activities, almost all women said that they require capital or financial support. The large majority also said they would need at least one additional type of support in the form of goods and materials, equipment or tools, training/guidance and/or a location to work from. 
However, the large majority of respondents said there are potential risks from starting or expanding their livelihoods. Risks identified include robbery or fraud, violence from intimate partners or other relatives, and exposure to GBV, humiliation or economic abuse from a husband or family member. Women are also concerned about the risk that their business may fail, mostly due to the economic situation caused by the current crisis in Gaza. A small number of women raised concerns that they could be exploited by the organizations seeking to support them and their livelihoods.

More than half of the women survivors of GBV interviewed said that members of their community engage in sex work as a means of livelihood. In about $41 \%$ of the cases mentioned, women and girls are forced to sell sex for money by a family member. The most common situation described by the respondents is women being made by their husbands to engage in sex for money, and the next most common situation is girls being forced by a parent (usually her father) or other family member to have sex for money. In some cases, women or girls decide to exchange sex for money or food, sometimes called 'survival sex'.

Adolescent girls are not able to work outside the home according to cultural norms in Gaza, which has had a protective effect on their education: unlike boys, girls are not removed from school in order to participate in livelihoods activities. However, the economic crisis in Gaza has impacted households' ability to pay for both girls' and boys' school expenses and can contribute to difficult home environments. Adolescent girls are at increased risk of early marriage because of the lack of money to continue their education and their inability to work outside the home. Despite the cultural restrictions, adolescent girls identified a number of permissible livelihoods opportunities along with the types of support they would need, though risks of engaging in these strategies include sexual harassment, domestic violence, and violence/threats from non-family members. A broader range of permissible livelihoods opportunities were identified for adolescent boys, although these also come with potential risks including verbal or physical abuse, theft or fraud, sexual harassment, and exploitation. Some types of risks that were identified for adolescent boys were not raised for women or for adolescent girls, including recruitment by Israel as a spy.

As the findings of this analysis show, there are significant needs related to livelihoods - and significant risks. The large majority of women survivors of GBV interviewed $(74 \%)$ said that they do not currently utilize any strategies to prevent or mitigate risks in any current livelihoods activities. However, the women interviewed and the adolescent girls and adolescent boys who participated in the focus groups identified a wide range of potential prevention and mitigation measures that should be incorporated into any future livelihoods support activities. These prevention and mitigation strategies are broken down by cohort and by risk, and presented in Section 5 of this report. Examples include identifying safe workspaces such as women's centres and cooperatives, linking with formal financial services, sensitization and outreach to change attitudes towards women working outside the home, training in business skills including negotiation and invoicing, and utilizing existing referral pathways to obtain legal and other services when needed. 


\section{INTRODUCTION}

Livelihoods are an essential way for crisis-affected people to cope with and recover from shocks. Support to livelihoods in an emergency can improve access to food and basic needs, help reduce the need for people to rely on negative coping strategies, and support improvements in overall wellbeing of individuals and households as income increases and stress is reduced. At the same time, unsafe livelihoods strategies, violence and insecurity, control of assets and gendered power dynamics can instead turn livelihoods into liabilities. Humanitarian activities can unintentionally increase risks associated with livelihoods activities, including the risk of Gender-Based Violence (GBV). Gender risk analysis can inform programme design so that safe livelihoods initiatives can be supported by humanitarian actors.

In March and April 2019, Oxfam conducted a Cohort Livelihoods and Risk Analysis (CLARA) in the Gaza Strip in the Occupied Palestinian Territory (OPT). The study was conducted as part of a project designed and implemented by Oxfam and its partner the MA'AN Development Center, to address food insecurity and protection needs in the protracted emergency taking place in North Gaza. The project will support immediate food security of families affected by protection threats by supplying fresh-food vouchers, provide livelihoods support to women who are survivors of GBV, target severe protection cases with cash for protection needs, and conduct research and influencing on social protection.

CLARA is an approach to understanding risks related to livelihoods activities, including GBV, and potential risks from livelihoods programming (the latter is an example of what Oxfam refers to as safe programming). The CLARA study in Gaza is primarily intended to inform Oxfam's understanding of the gendered risks associated with livelihoods, risk mitigation and prevention strategies, and the needs and opportunities of women who are survivors of GBV in Gaza. This report also provides some information on these areas for adolescent girls and boys. These findings will be used to inform the implementation and monitoring, evaluation, accountability and learning (MEAL) of the Oxfam and MA'AN Development Center project, as well as to provide the humanitarian community with a broadly representative picture of livelihoods, risks and opportunities among women in Gaza who are survivors of GBV.

Because of the objective and design of this analysis, data collection was limited to three cohorts: adult women survivors of GBV, adolescent girls, and adolescent boys. Focus group discussion (FGDs) and interviews were not held with specific livelihoods groups, wealth groups, refugees, persons with disabilities or the elderly, though the women and adolescents who participated in the FGDs do broadly represent a wide range of characteristics and fall into various groups. As a result, the findings of this report are primarily organized according to the three cohorts.

All quotes included are approximate representations based on notes taken by the data collectors.

The CLARA guidance and Arabic interview tools ${ }^{2}$ were used with light adaptations for the context. The questions can be found in the Annex. 


\section{GAZA CONTEXT}

The Palestinian territories have been occupied by Israel since 1967, and this together with the 2007 Israeli-imposed blockade following the takeover by Hamas affects every aspect of life in Gaza. ${ }^{3}$ The Gaza economy has gone into 'free fall' as a result of the blockade, ${ }^{4}$ and alongside three escalations of hostilities (in 2008, 2012 and 2014), basic infrastructure, service delivery, livelihoods and coping mechanisms have been devastated. Conditions have been further exacerbated by the complete loss by 2003 of Gazans' access to work in Israel, the closure of the border crossing with Egypt in 2014, and by fluctuating restrictions on the only crossing for goods, Kerem Shalom. The situation has been further worsened by a division between the Palestinian Authority (PA) in the West Bank and the de facto Hamas authorities in Gaza: in 2017, the PA imposed restrictions in response to Hamas' establishment of a parallel institution to run local ministries. These included reducing the salaries of PA employees in Gaza by 30 $50 \%$, forcing the retirement of around 58,000 PA public employees in Gaza, and delaying cash assistance for over 74,000 vulnerable households. ${ }^{5}$ These measures by the PA have further affected the economy and the livelihoods of thousands of Gazan families. The Gaza Strip has one of the world's highest population densities and the population is expected to reach 2.1 million by 2020 .

Figure 1: Unemployment rate in Gaza, West Bank and Israel, 2017-2018

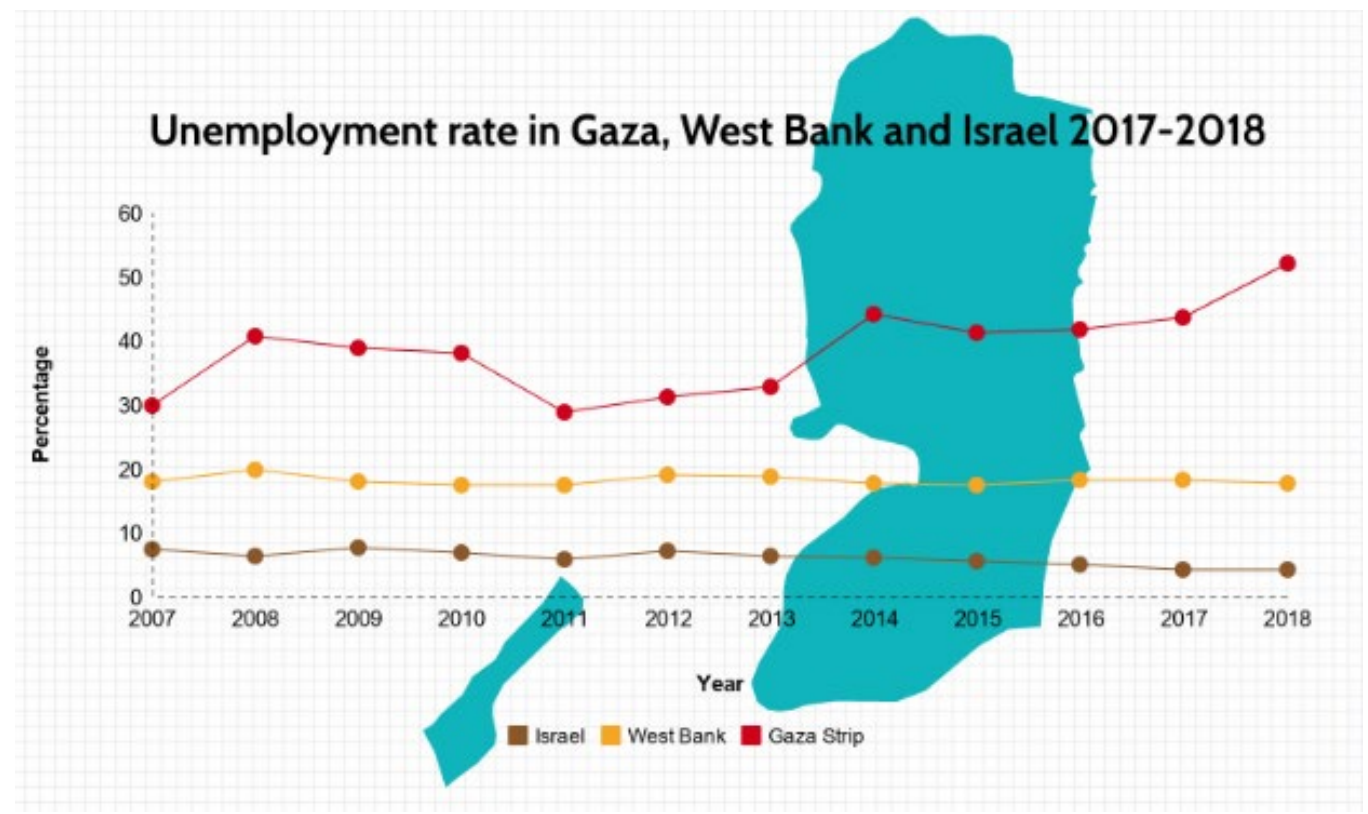

Image source: Gisha Legal Center for Freedom of Movement ${ }^{6}$

Gaza has the world's highest unemployment rate, at $52 \%$ in 2017 - an increase of almost $8 \%$ since 2017 and more than $20 \%$ since the blockade began in $2007 .{ }^{7}$ Among women, the unemployment rate is almost $75 \%$, and among youth (ages 15-29) it is $69 \% .{ }^{8}$ Levels of funding reported to the Food Security Cluster for livelihoods activities are extremely low, with a funding gap of $91 \%$ in late $2018 .{ }^{9}$

Women's labour force participation in Gaza is among the lowest in the world, with economic activity largely concentrated in unpaid agricultural work or informal employment. ${ }^{10}$ Women's livelihoods in Gaza are constrained by gender roles. For example, although women constitute $30 \%$ of agricultural employees, they are often classified as 'unpaid family members' and do not 
have access to an independent income or control over agricultural assets. Social codes confine women and girls to their homes, limiting their livelihoods opportunities and keeping them reliant on male family members for income and for access to information around livelihoods opportunities, services, humanitarian assistance and security. An electricity crisis in Gaza also has serious impacts on women due to their gendered responsibilities around domestic labour and care: all household tasks that require electricity - such as laundry, cooking and children's study - can only take place when it is available, which is usually during the night. ${ }^{11}$ Gendered roles, responsibilities and restrictions on women and girls in Gaza 'often translate into their exclusion and limited role in decision-making within the household and beyond'. ${ }^{12}$

The high unemployment and resulting high poverty are the main drivers of food insecurity: according to the preliminary results of the Socio-Economic and Food Security Survey (SefSec), over $68 \%$ of households in Gaza were severely or moderately food insecure in $2018 .{ }^{13}$ Food insecurity and inability to meet basic needs is one of the most significant and ongoing concerns of the Palestinian community, despite $69 \%$ of the population of Gaza reporting that they received some type of humanitarian assistance in 2018 . The current rate of food insecurity represents an increase of $9 \%$ compared to the last SefSec assessment in 2014 . The prevalence of food insecurity is quite significantly higher in Gaza than in the West Bank, and in Gaza it is roughly the same (ranging from about 65-70\%) across all household categories: both urban area and refugee camps, and both refugee and non-refugee households.

Recent Oxfam needs assessments and other analyses in Gaza show that negative coping strategies are common. These include hazardous work for adults and young children (6-12 years) for low pay (5-10 Israeli new shekels/ILS per day, or \$1.4-2.8) and forced early marriage for girls in poor households. Eating less preferred food is common, and women in particular also reported limiting or reducing their food intake due to lack of food, and going to bed hungry in order to prioritize food for children and men. Dropping out of school is also reported as a coping mechanism. Overall, assessments show that women and girls are subject to more or worse negative coping strategies than other groups.

According to UNFPA, 'the protracted humanitarian crisis in the occupied Palestinian territory and its impact on especially the Gaza Strip due to the blockade, has exacerbated GBV in all forms, including sexual violence, domestic violence and child marriage'. ${ }^{14}$ Among GBV survivors, $17 \%$ experienced resource denial as a form of abuse. ${ }^{15}$ A survey on GBV in Gaza in 2010 found that the majority of incidents of violence reported by women took place in the home, with spouses as the main perpetrator among married women (this is often referred to as Intimate Partner Violence, or IPV). ${ }^{16}$ Among married women, this research showed that about $35 \%$ reported physical violence, $76 \%$ psychological violence and $15 \%$ sexual violence. These figures had all increased since the previous study in 2005 , with a $23 \%$ increase in psychological violence in particular. Women in the poorest households and younger married women (15-19 years) were more vulnerable to recurring physical violence. Adolescent girls and boys are also particularly vulnerable to protection concerns, including physical and emotional violence, sexual abuse, arrest and detention, child labour, recruitment and use by armed groups, and early marriage. ${ }^{17}$ Conversely, higher age, higher levels of education, more employment and a better household economic situation are associated with reduced levels of violence and abuse towards women in Gaza. ${ }^{18}$ 


\section{METHODOLOGY}

\subsection{OVERVIEW}

The primary respondents in the data collection were 70 women who have experienced GBV and are part of the formal case management system in Gaza. The women receive services from a women's health centre - a partner of Oxfam and a key stakeholder in the project under which this exercise was conducted - and were selected by their case workers. The women's centre was selected as it serves the targeted area of North Gaza and it has accumulated experience in comprehensive multi-sectorial GBV service provision modalities including psychosocial support, legal support, social mediation, medical primary care and recreational activities. The centre uses the local information management system and is part of the referral pathways operating under the local standard operating procedures (SOPs) designed and validated by the GBV subcluster and used by GBV service providers all over the Gaza Strip.

A subset of the women interviewed will later be targeted for livelihoods support (training and cash) through a separate process. Because of the linkage between this analysis and the upcoming livelihoods support project, the interviewees were nominated by case workers from the larger pool of women who are clients of the centre, based on two main factors:

1. A GBV survivor who entered the case management system, and received multi-sectorial services as needed and documented in the GBV information management system: this is to ensure adequate access to background and case history data that Oxfam can't collect first hand, and to make sure those women are in the recovery phase where priorities can be related to improving quality of life and preventing recurrence of GBV.

2. The identified root cause of GBV is poverty or livelihood hardship: this is to enable examination of the reported link between poverty and an increase in GBV, and how livelihoods support intervention has a remedial effect in reducing/preventing GBV.

In order to protect their confidentiality and safety, key informant interviews were held with each of the women privately and conducted by external data collectors who were trained and supervised closely by Oxfam staff.

One FGD was held with adolescent girls and another FGD with adolescent boys. Those boys and girls were selected randomly from among the children and family members of the targeted women, from the age group 14-18. Because adult women are the target population for this project, the primary objective of the FGDs with adolescents was to understand risks or threats that could be experienced by the children or other household members of these women as a result of their involvement in livelihoods activities. However, the FGDs also provided information on the risks faced by adolescents overall.

The data collection took place over a period of two weeks, in the last week of March and first week of April 2019. A few days' delay was experienced due to a security escalation, during which field work could not be conducted.

A data collection team was selected from a local consultancy firm with good experience in field work. Oxfam gender and protection staff conducted a two-hour training and coaching session on the data collection. During the session, Oxfam staff gave the team information on the project and the objectives of the analysis, and provided training on the particular considerations in collecting data from GBV survivors. Oxfam's MEAL staff then went through the CLARA tool 
question by question, providing coaching on how to use the tool, record data and time of interviews, and other data collection considerations.

Close contact and follow-up for the data collection team was maintained throughout the data collection phase and daily feedback was exchanged. Privacy and confidentiality were especially considered due to the highly sensitive data collected and discussed during the interviews.

Several simple but effective precautionary steps were taken to achieve this: separate rooms were designated for different interviews taking place simultaneously by the data collection team members. When the women arrived for the interview, a cover page of their identifiable data (name, age, family members, address, phone number, etc.) was filled out by Oxfam's gender and protection staff or the women's health centre coordinator, and a simple numerical code was given to the woman. She provided only the code to the data collector, so that her identity was not revealed to her/him. There were three female and one male data collector, and women could choose by whom they preferred to be interviewed. The collected data was then entered into a simple excel data sheet using the numerical codes instead of names. The list of names and identifiable data were kept separate, with no references to the GBV conditions of the women in it.

The male data collector led the FGD with adolescent boys and a female data collector led the FGD with adolescent girls to support more open discussions about sensitive topics.

\subsection{DATA PROTECTION}

Oxfam is highly committed to the 'General Data Protection Regulations' (GDPR) which were approved by the EU Parliament on 14 April 2016 and enforced on 25 May 2018 for all EU organizations. In parallel, Oxfam also has a Privacy Statement as well as a 'Responsible Programme Data Policy' which applies to the processing of personal information, including the 'Primary Change Agents/Target Population' which has been updated to align with the GDPR.

In this project, Oxfam staff in Gaza fully adhered to these policies and commitments to the GDPR, in consultation with the Oxfam data protection global platform.

The main concern faced by the project and MEAL teams was around local partners' ability to secure beneficiary data collected by their staff and stored to their systems. The MEAL team, in coordination with data protection protocols, raised two main concerns: to what extent are partners systems safe and secured, especially for GBV and child protection cases; and how will partners and Oxfam share data responsibly while partners' emails are not guaranteed to be secure?

The data collection process slowed down as a result of these two concerns, as measures were put in place to ensure privacy and protect against information leaks. The whole process was carefully supervised by Oxfam gender and protection staff. The first concern was handled through direct and strict supervision by Oxfam on the selection process, using the coded system explained above to protect personal data from being exposed or leaked. The second concern was addressed through using one database for the interview data, which was stored without personal information, while a separate database containing sensitive data was entered by Oxfam staff and saved in Oxfam's secured system.

All mitigation measures taken are considered highly secure and there is zero tolerance of leaks of personal data. At the same time, this project triggered discussion on data protection issues with Oxfam partners, who usually do the selection process and create databases including personal information; it also highlighted issues of data protection with external consultants who conduct baseline/endline reports, evaluations and other forms of data collection. 
This discussion still ongoing between the country and the global data protection team to secure the needed resources for partner capacity building in data protection knowledge, attitude and practices. 


\section{FINDINGS}

\subsection{ADULT WOMEN GBV SURVIVORS}

\subsubsection{Livelihoods activities and impacts of the Gaza crisis}

Almost $76 \%$ of women reported that their livelihood or the livelihood of a spouse or family member has been affected by specific shocks within the Gaza context. Among those who reported that their livelihood has been affected by a specific shock, $62 \%$ said the primary impact is from the PA restrictions in 2017. The impact of the blockade by Israel in 2007 has had the second largest impact, as seen in Figure 2.

Most of the effects reported by women related to their husband's livelihood being impacted by the PA restrictions or blockade, or other conflicts. About $18 \%$ of the women said their own livelihoods or jobs had been affected, and were primarily affected by PA restrictions. Other impacts reported as a result of shocks were the reduction of household income or family support, again primarily because of PA restrictions.

After the blockade in 2007: 'My husband used to work in dressmaking and get a suitable income to meet his family's needs. Currently he works irregularly and for very low wages that are not enough to meet our needs.'

After PA restrictions in 2017: 'My husband is a PA employee, paying back a loan. After the PA salaries crisis, he doesn't have any salary left [after loan repayment].'

After Gaza's first war, in 2008: ${ }^{19}$ 'I used to work in an apiary, producing and selling honey, but it was bulldozed in 2008 in Operation Cast Lead.'

Figure 2. Type of shock affecting livelihoods (among those who reported impact)

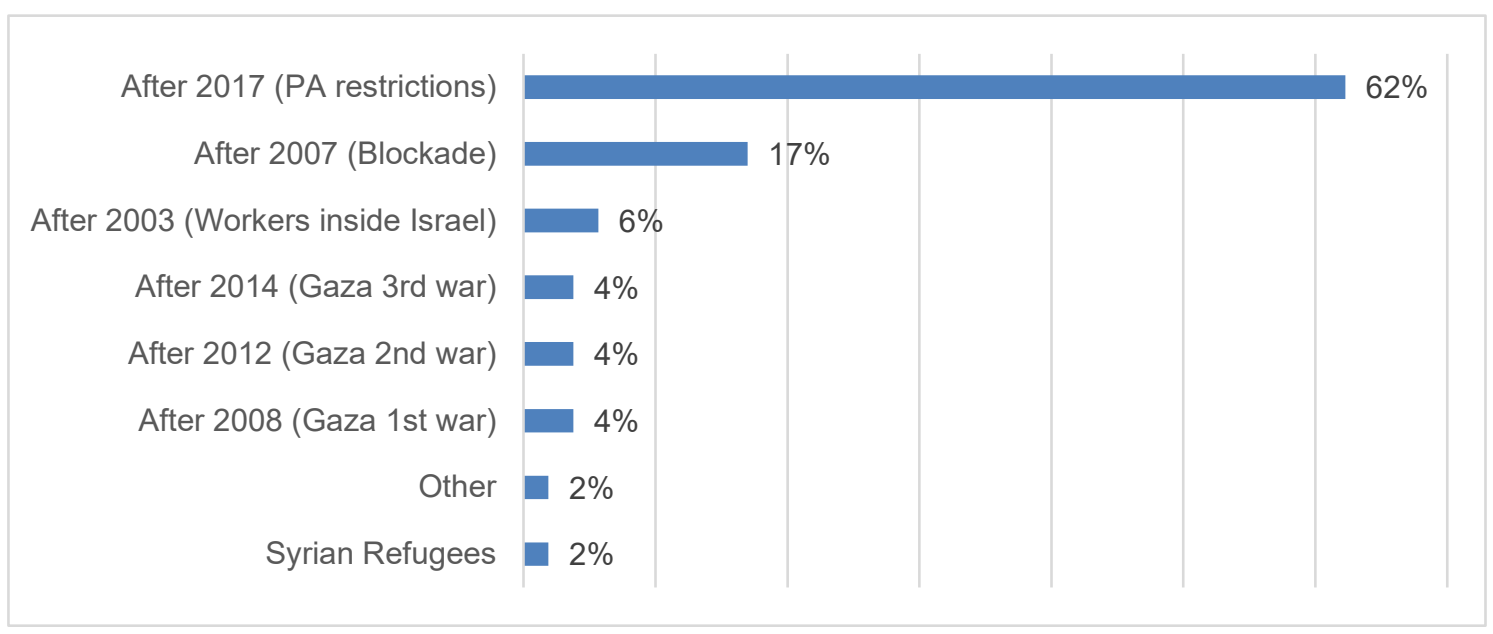

The most prevalent way that the women survivors of GBV who were interviewed meet their basic needs and access money is through support from others. For most women, this is social support, such as United Nations Relief and Works Agency (UNRWA) food assistance, but 
frequently women also rely on support from relatives such as parents or siblings. A few women reported relying on charity from neighbours, or even begging to survive.

'The family lives on assistance. I worked for a while as a cleaner in a clinic but my boss didn't pay me fairly, so I left.'

'My husband is elderly, a psychosocial patient and unemployed. The family lives on social assistance. I have two adult sons who are unemployed.'

'I am currently going through divorce proceedings as [my husband] used to violently beat me and the children on a daily basis for no reason. I currently live with my six children in my 85-year-old father's house, and live on the charity of my brothers.'

Women interviewed practise a range of livelihoods activities; these are mostly highly gendered strategies based around activities that are typically done by women, as these are more permissible in the context. Activities include embroidery, crochet, cooking or food processing, hairdressing and dressmaking. However, women are primarily doing these day-to-day or just occasionally, mostly upon request. Some activities are seasonal, such as making cookies for Eid or tutoring during exam periods.

'I make embroidered pieces on request at my home.'

'I work at home in educational support for students - paid tutoring - especially during test seasons.'

'I work in hairdressing on an irregular basis, according to the needs of salons.'

About $15 \%$ of the women interviewed reported income from Gaza or PA employment. It is the woman's husband - not the woman herself - who is employed in all but one case. Almost all the women said that this salary does not provide adequate income for the household, though sometimes they provided additional explanations pointing to other challenges with their spouse.

'My husband receives 1,000 ILS of his salary every two months. The family lives on that and UNRWA food assistance.'

'My husband is a drug abuser and his salary is not enough to cover his family's needs.'

'I am a PA employee and my husband lives in the West Bank. I am the only provider for the family.'

The majority of women mentioned only one source of income, with only about $20 \%$ of respondents stating more than one source of income. The women who mentioned more than one source are primarily those who carry out day-to-day income-generating activities such as embroidery and cooking, or are women who reported receiving support from others as their main income source. Some of those who reported receiving support from others rely on multiple forms of assistance, for example social support such as food aid and also support from family members, while others receive social support and also conduct some livelihoods activities like sewing. Figure 3 shows the various types of income sources mentioned by the women, including multiple responses for some households. 
Figure 3. Types of income sources among adult women (frequency)

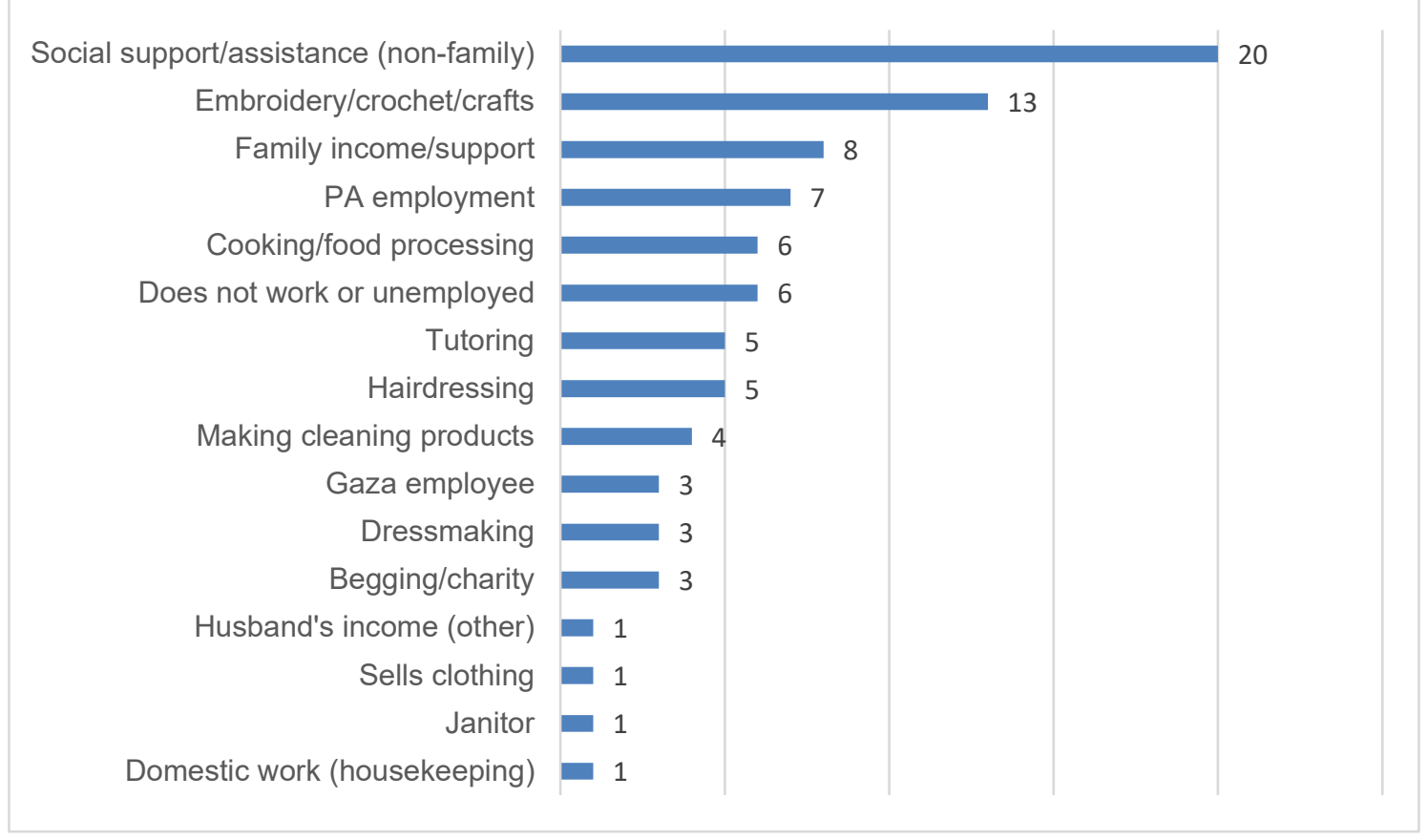

All but one woman reported some change to their livelihoods as a result of the overall crisis in Gaza. Most of these changes are negative, though some women also reported a few positive changes. Figure 4 summarizes the most frequently mentioned changes.

The most frequent responses relate to having limited income, selling gold dowry and other assets, taking on debt, stress on the family and in relationships (often between the husband and wife), not having work available, and negative effects on children's education including having to leave school or not being able to start school due to lack of money.

'There is no demand for embroidery products. I had to sell my gold to meet basic needs.'

'There is psychological pressure and family disputes. My husband spent eight months in prison for owing debts.'

'There's no source of income for the family. I sell UNRWA's food assistance to meet our basic needs.'

Positive changes reported include gaining new skills, experiences or knowledge as a result of livelihoods activities, earning income for the household, and feeling a sense of self-dependence from working.

'I now have a salary to live on, as well as practical experience.'

'I am improving my skills and self-development, and applying what I've learned to make my business successful. I am achieving a good social position among people and getting a small income to live on.'

Most women reported multiple changes to livelihoods. Figure 4 shows the frequency of all changes mentioned. 
Figure 4. Changes in livelihoods due to Gaza crisis (frequency)

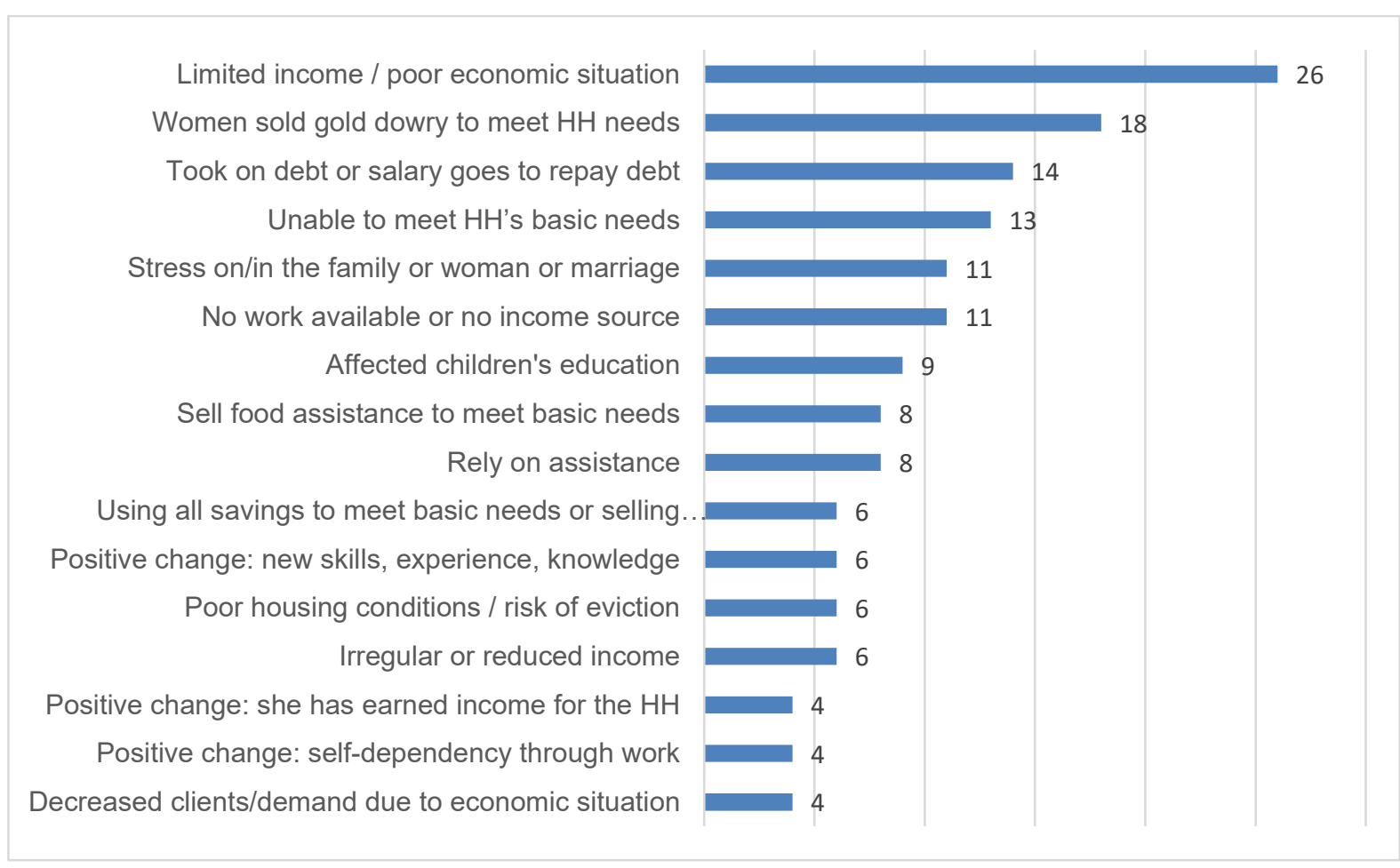

\subsubsection{Risks from current livelihoods activities}

Women said that their livelihoods activities are often risky, and that this risk has increased significantly as a result of shocks in the context and the Gaza crisis. Some $39 \%$ of women interviewed said that their current livelihoods activities make them feel vulnerable or unsafe (see Figure 5). By contrast, only $7 \%$ of women said that their livelihoods activities were unsafe before the crisis in Gaza. There are no cases where women said that their livelihoods activities used to be unsafe before the crisis but are now safe. Overall, $38 \%$ of the women said that risks have increased due to the current crisis. The ways that women said their activities make them feel unsafe are described below.

Figure 5. Are there livelihoods activities you do now that make you feel vulnerable, unsafe, or less safe?

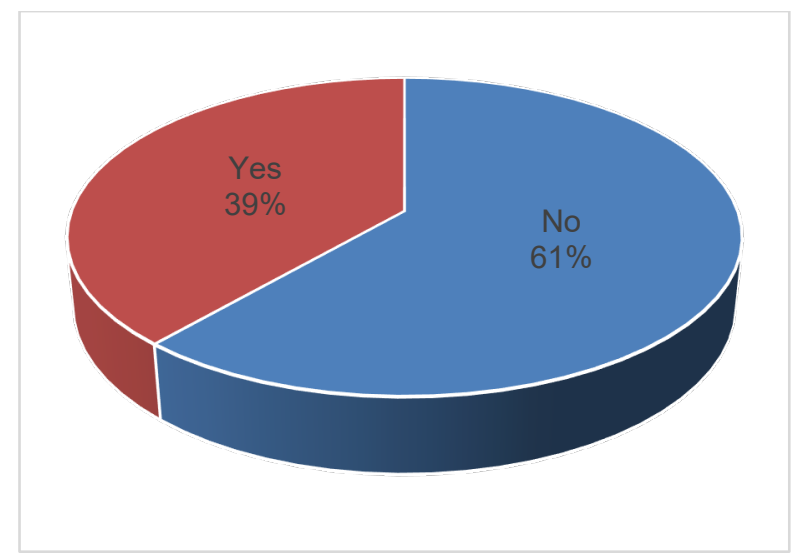


The primary threat women said they experience now is due to economic vulnerability: the effects of being unable to meet the household's basic needs due to low wages and limited income opportunities. They live on charity and debt, can't find income opportunities and fear falling into further destitution.

'Due to the worsening economic situation, I can't work in selling clothes any more as I lack money. No one supports me and I live on charity.'

'The family's situation is much worse, and debts have accumulated.'

'I worry that people won't be able to pay for the private tutoring and that my work would have been lost without returns.'

'My kids beg for food from markets and neighbours. I fear I will have to engage in sin as a result of inability to provide for my family's needs.'

Women feel at greater risk of GBV or other harm due to their current livelihoods strategies. This is due to strategies that include working in male-dominated spaces such as markets, having to walk for long distances or spend long periods outside selling goods, or working in private homes.

'There is a danger of getting robbed. I don't feel safe when distributing products to shops.'

'I have to walk for a long distance every day to get to the women's centre. It takes me two hours to walk to the centre and two hours to walk back, which puts me at risk walking all this distance alone.'

'I buy materials from the market where sellers are usually men, which exposes me to risks of sexual harassment.'

'My family has to send the two kids (less than 18 years old) to collect scrap metal from the street to sell for very little money, which puts them at risk.'

'Going to people's houses to work is dangerous.'

Women also feel vulnerable due to humiliation and loss of dignity caused by their food security and livelihoods strategies. In Gaza, cultural importance is placed on traditional gender roles, with respect given to men as breadwinners and to women as housewives. Women feel humiliation in part because they have to take on responsibilities to provide for themselves and their families, and in part because the strategies they have to use to get food or income are not considered decent or respectable. Women expressed feeling humiliated as a result of the words or actions of relatives, traders in the market, and neighbours or other community members.

'I feel humiliated by sellers who ridicule my work.'

'Going to the centre to take courses puts me in a situation where relatives gossip about me, object to me going out, and even harm my reputation.'

'I go to the market at the end of the day to get the left-over vegetables for lower prices, which exposes me to insults and gossip.'

'The community mocks me due to my situation. I go to the market late so that vendors give me the left-over food. I ask for assistance from unknown and untrusted people.'

Women experience IPV or domestic violence due to their economic situation. Some linked this to stress around survival and providing for the family. 
'As a result of the difficult economic situation, my husband commits all kinds of violence against me and my kids.'

'Me and my kids are repeatedly subjected to physical and verbal violence.'

'Violence from my husband has increased because of the worsened economic situation.'

'I am suffering ongoing violence, verbally and physically, because of the very bad economic situation of the household.'

Among the women who said risks have increased due to the Gaza crisis, the most frequent explanation given for why risks have increased is economic vulnerability and inability to meet basic needs. Risk due to livelihoods activities, IPV and women having to enter the workforce rank as the second, third and fourth reasons respectively (see Figure 6). Other reasons relate to having fewer customers, lack of economic opportunities and increased stress. Some women mentioned more than one impact of the crisis.

Humanitarian actors would not necessarily consider vulnerabilities such as economic hardship or a reduction in customers to be 'risks' from a protection perspective. However, these are threats from a food security and livelihoods perspective, and it is useful for NGOs to understand how women survivors of GBV in Gaza see risks and vulnerabilities more holistically.

Figure 6. How risks are increased as a result of crises/shocks (frequency)

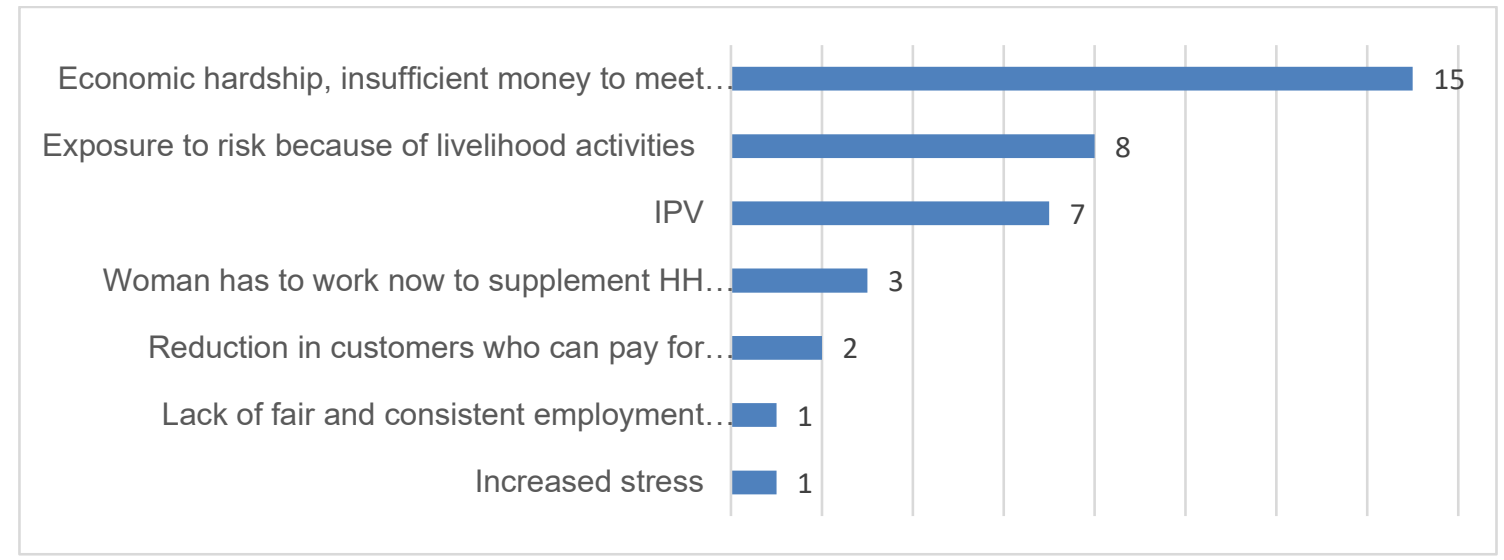

\subsubsection{Protection strategies}

The large majority of women (74\%) said that they do not currently utilize any strategies to be safer, despite the risks they experience. The strategy that was mentioned most is travelling only in groups, with small percentages of women mentioning additional strategies to be safe (see Figure 7). Overall, $93 \%$ of women said that they did not take any actions to be safer before the crisis: the strategies that have increased the most are going to places in groups, and avoiding going out at certain times or using certain routes.

Women were asked if they took any 'serious actions' to be safer, but only one responded positively, saying she is avoiding some places. No other women reported taking any serious actions. 
Figure 7. Strategies to be safe now

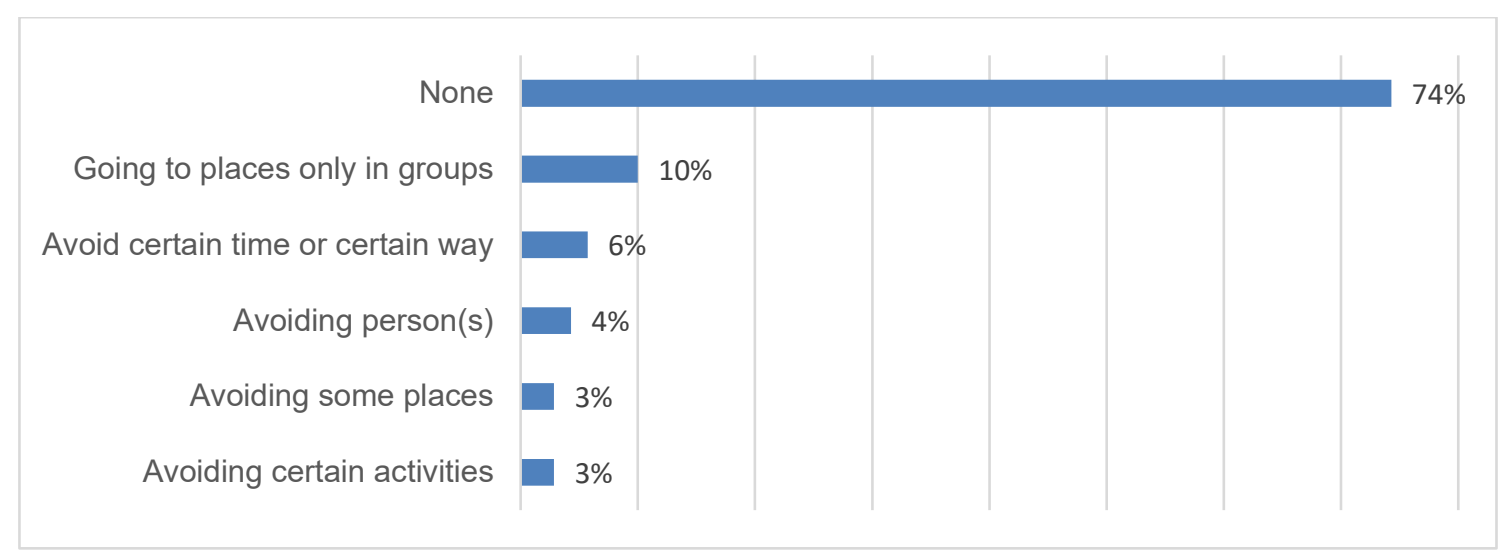

\subsubsection{New or improved livelihoods opportunities for women and support needed}

The women survivors of GBV listed a range of livelihoods activities that can be done by women in Gaza. In order of frequency, the most common responses were:

- Sewing, embroidery and crochet

- Making cakes, pastries and sweets

- Hairdressing, working in a beauty salon

- Making and selling cleaning equipment and products

- Making crafts and decorations

- Food processing and making food products, such as jams and pickles, drying fruits and vegetables, making spices or freezing foods

- Raising poultry and selling eggs

- Dairy products and cheese making

- Working in educational support centres, or providing training or tutoring

Other activities that were mentioned less frequently include trade, agriculture and farm work, other types of animal rearing (e.g. rabbits), childcare, and selling clothes or other retail.

The activities that the women proposed to improve their own livelihoods and income are largely in line with what they see as the activities that are appropriate for women in Gaza. Women are particularly interested in starting or expanding market-based businesses (see Figure 8). The largest number of women are interested in starting or expanding businesses related to sewing, embroidery, crochet or dressmaking. Other popular areas of interest are in education (tutoring, opening education centres) and childcare, opening grocery stores or produce stands, and starting or expanding businesses to make and sell cleaning equipment and products. Other types of small businesses include arts and crafts, gift shops, wedding businesses, dry cleaners, making or selling perfume and other cosmetics, bookshops, gyms or other small shops. A few women also mentioned wanting to incorporate a distribution component to their business, such as by having a tuk tuk.

The majority of women (84\%) want to start new income-generating activities or businesses, while a smaller number (16\%) proposed expanding existing activities.

Some women mentioned interest in a few different activities. For the purposes of the graph 
below, multiple activities are included if more than one was listed by the respondent. However, this also shows that some women have not yet clearly identified activities and may not have a well-developed business idea.

'I want to open a small grocery shop to work in with my husband.'

'I want to expand my work in embroidery and crochet by starting a small business and marketing products online.'

'I want to start a new business of dry cleaning or raising poultry.'

'There is a room in my house on floor level that overlooks the street and could be used to open a shop.'

'I want to start an educational support centre, as I have related experience, or an eggs incubator as I also have experience in this, or a hairdressing salon as I previously worked in one for a while.'

Figure 8. Activities to improve livelihoods and income now

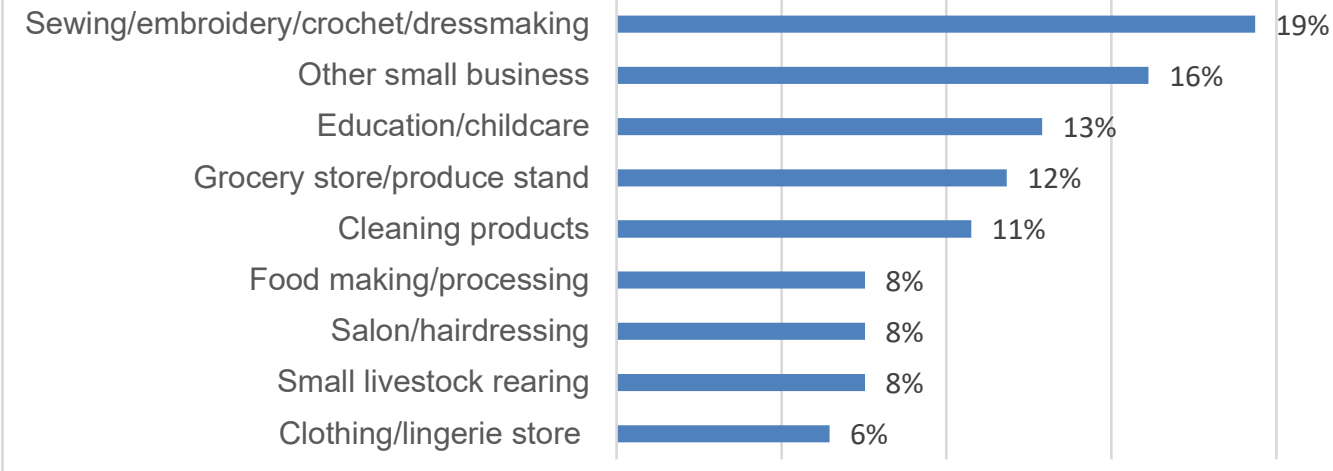

In order to start or expand their livelihoods activities, almost all women (about 94\%) said that they require capital or financial support. The large majority also said they will need at least one additional type of support in the form of goods and materials, equipment or tools, training/guidance and/or a location to work from (see Figure 9). Some women already have a suitable place to work from (about 23\%).

Figure 9. Support needed by women survivors of GBV for new livelihoods

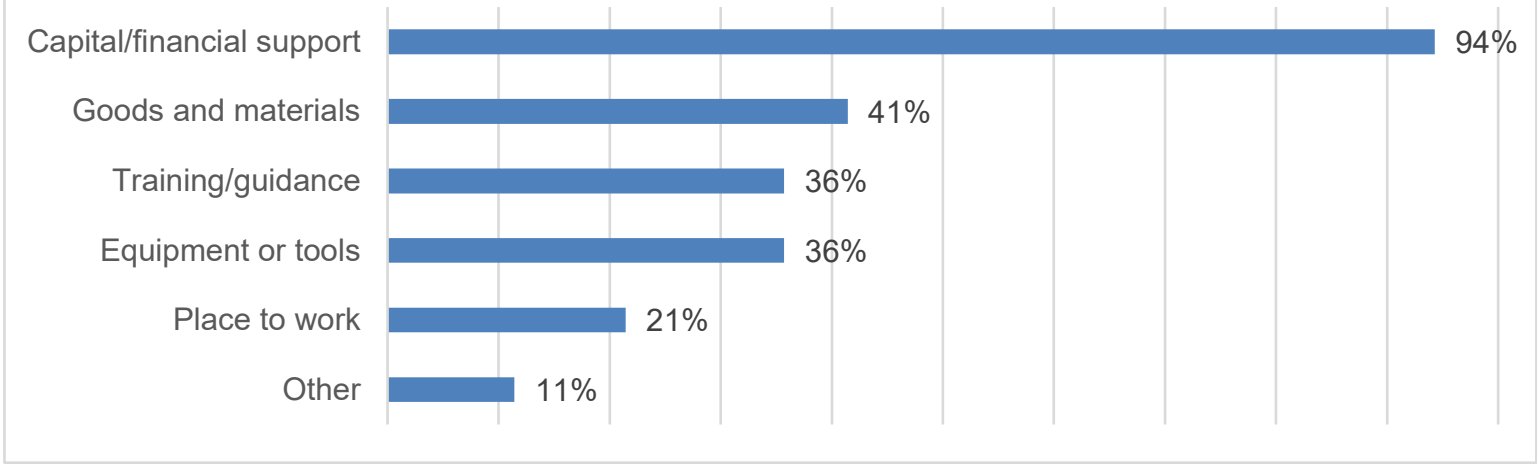


A few women mentioned other types of support needed. These include specific areas like facilitation from the Ministry of Education, and more general areas like support from the community. A few women also seemed to indicate that they would need support with basic needs, such as social support or support from charities.

\subsubsection{Threats and risks from new livelihoods opportunities for women}

Respondents were asked about threats women in Gaza could face in conducting livelihoods activities (not specific to their own situation). The large majority of women $(76 \%)$ said that women in Gaza could face risks from starting or expanding their livelihoods. Two main risks were identified: IPV or violence from other relatives, and exposure to sexual harassment and other forms of GBV. These potential threats were each mentioned by about half of the women. The other main potential risk mentioned by the women was fraud or robbery $(17 \%$ of respondents).

The majority of women said there are potential risks to themselves associated with starting or expanding their own livelihoods activities (see Figure 10).

Figure 10. Are there risks you might face from receiving livelihoods support?

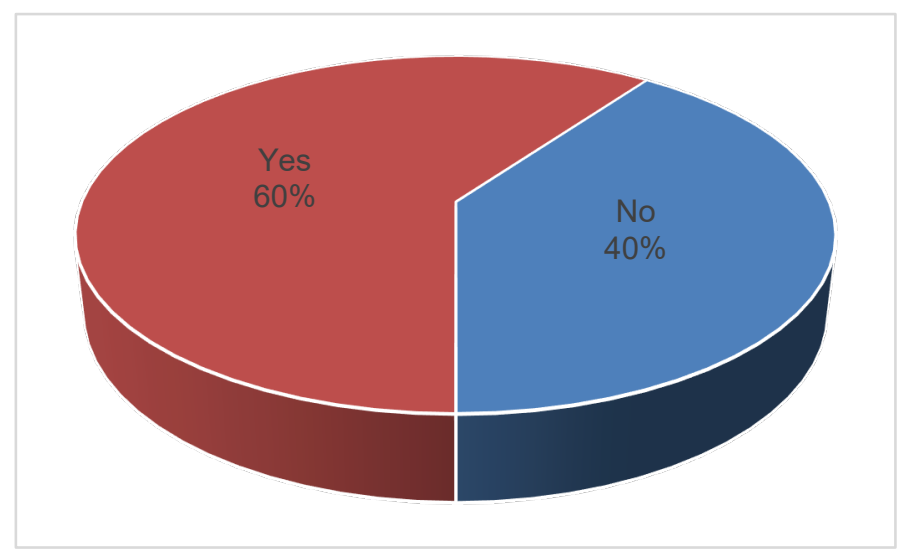

Figure 11 shows the main types of potential risks identified by the $60 \%$ of women who said they could personally face risks in starting or expanding their livelihoods activities. Some women mentioned more than one type of potential risk.

Figure 11. Potential threats and risks for women survivors of GBV from new livelihoods opportunities (frequency).

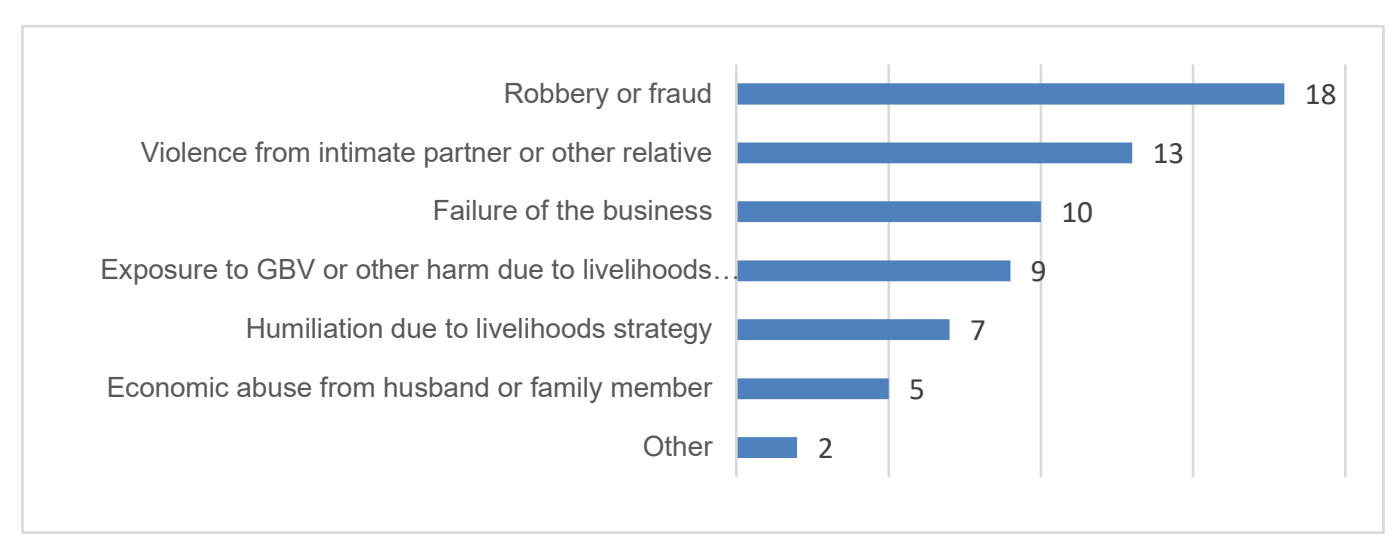


The risk mentioned most frequently is robbery or fraud. Women expressed concern over robbery or fraud in general, but some also mentioned the risk of robbery/fraud at the hands of clients, neighbours, friends or other people known to them, by not paying for goods. A few women said there is risk of theft of equipment they would use for their livelihood because they have no safe place to store the materials. Some women were also concerned about theft carried out by a husband or other family member, but these threats are not included here (see below, under economic abuse).

'There is a risk of exploitation and non-payment by clients.'

'There is a risk that a neighbour might rob me, as I live without a husband.'

'There is a risk of theft of my equipment.'

The next most frequently raised threat by women is violence from their husband (IPV) or other relative. Violence from intimate partners or other family members includes both physical violence and psychological violence. As discussed in section 4.1.2., a number of women reported that they already experience IPV or domestic violence due to their economic situation - not having enough money to meet basic needs and/or the reduction in their husband's income - and the resulting stress. The comments from some women indicate that improving the family's economic status through livelihoods activities may reduce the current violence - but that new tensions could arise between them and their husband or other family members around access to and control of the money or livelihood assets, and around women working. Some women talked about risks related to cultural norms, where husbands or relatives may try to stop women from having a livelihood or leaving the house.

'There may be unrest and disputes with my husband and relatives.'

'There is possible violence from my husband.'

'There could be tensions and interference by my stepsons.'

'There is a risk that husbands or relatives would not allow her to work outside the home and would beat her.'

Women are concerned with the risk that their business may fail, mostly due to the economic situation caused by the current crisis in Gaza. Some women also worry that they may not be successful in managing their business.

'There may be a lack of raw materials due to the Israeli blockade.'

'There's a risk of not being paid for private tutoring due to the bad economic situation.'

'There's a risk I wouldn't be able to manage the business on my own.'

'There's a risk of working for long hours for low pay.'

Women see a risk of GBV or other harm in conducting their proposed livelihoods activities. This is already being experienced by some women in their current activities, as revealed by some comments. Other types of potential harm mentioned include physical exertion and stress/pressure. One woman who wants to open a shop in her home talked about how she is 
already often subjected to sexual harassment, saying that men 'try to tempt me with money because I am in need'.

'Marketing and distributing products puts me at risk in my community.'

'Lack of a workplace presents a risk to me. Going to houses to market my products and carrying my goods from place to place is risky.'

'There's a risk of being insulted when I sell products and travel around to sell, and that I will get tired carrying and moving goods.'

Similar to what the women said they currently experience, they foresee risks of humiliation and annoyances due to new or expanded livelihoods activities. Women talked about the risk of gossip and other annoyances such as the spreading of rumours, teasing and verbal abuse from neighbours, community members or people in general.

'There's a risk of gossip and people's scrutiny.'

'There is a risk of insults from clients.'

Economic abuse from husbands or other family members is also a risk. Women specifically mentioned concerns that family members would try to take their business or profits. Although this could be combined with risks related to IPV/domestic violence or to theft, these threats are distinct from others in those categories.

'I fear my husband will come back to take over my business.'

'There is a risk of theft by my husband.'

'There is a risk of theft by members of my household.'

Finally, two women mentioned concerns about exploitation by organizations, and one specifically raised a concern about exploitation by supporting organizations. These are references to NGOs and community-based organizations that support women, but which could take advantage of them and their vulnerability by taking a share of the benefits they receive.

\subsubsection{Sex work as a livelihoods strategy}

A majority of women survivors of GBV said that members of their community engage in sex work as a means of livelihood (see Figure 12). In about $41 \%$ of the cases mentioned, women and girls are forced to sell sex for money by a family member. 
Figure 12 Do members of your community ever engage in sex work as a means of livelihood?

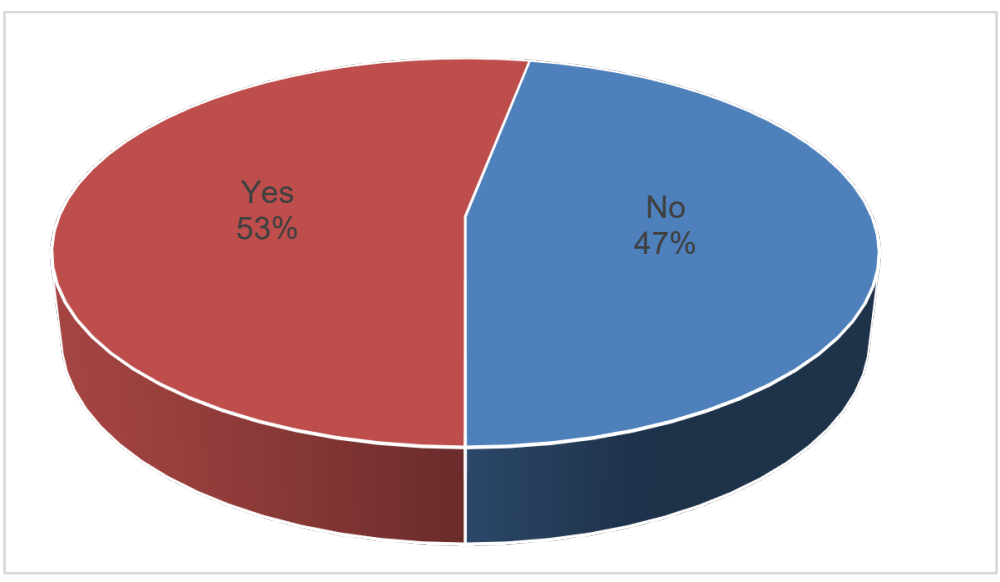

The most common situation described by the respondents is women being made by their husbands to engage in sex for money.

'A husband brings people to his house and forces his wife to have sex with them for money.'

'Due to the difficult economic situation, a man brings men to his house and sells his wife's honour for money.'

'A man sells his wife for money so he can have money to buy drugs and for his personal needs only.'

'A husband sells his wife's body for 20 ILS to get some cigarettes.'

The next most common situation described is girls being forced by a parent (usually her father) or other family member to have sex for money.

'A father trading his daughters' bodies for money.'

'Girls with disabilities especially are used by their families to work in such ways for money.'

'Husbands selling their wives' and daughters' honour for money.'

In some cases, women or girls engage in survival sex.

'They work in this field for money.'

'This phenomenon is widespread due to poverty. Women have to do this for money.'

'A female school student goes to the house of one guy to do this for money, without the knowledge of her parents.'

Prostitution houses, the involvement of taxi drivers and the connection with drug abuse were all mentioned by women.

'This is widespread among taxi drivers.' 
'Drug abuse is widespread.'

'Turning the family house into a prostitution house so that the head of family benefits from money.'

Incest was also mentioned a few times, including a case where a mother allegedly forced her daughter to have sex with her husband 'for fear that he might marry another woman'. One woman said someone had tried to recruit her into sex work: 'A person in one of the organizations offered me such work and I rejected them.'

\subsection{ADOLESCENT GIRLS}

\subsubsection{Adolescent girls' participation in livelihoods and the impact on their education}

Girls are not able to work outside the home according to the culture in Gaza, so this has had a protective effect on their education: unlike boys, girls are not removed from school in order to participate in livelihoods activities.

'Girls can't work outside the home so they commit to staying in school.'

'Only boys work. Girls stay at school.'

'Boys come out of school to work. There are threats to girls to take them out of school, but to sit at home and not work.'

However, as discussed above in section 4.1.6, some girls are forced by a parent or other family member to have sex for money, or practice survival sex due to lack of other income opportunities.

Girls are affected in other ways by the crisis in Gaza. Both women survivors of GBV and adolescent girls agree that the economic situation due to the crisis means that there is often not enough money available in households for educational expenses such as school uniforms, transportation and supplies like books and stationery. This has meant that some young children have not been enrolled in kindergarten or older adolescents have not been able to go to university. Families may not be able to afford private tutors for girls who need them.

'The family is unable to provide school needs for the kids. They walk very long distances to school, and are unable to buy school uniforms.'

'We have been unable to meet school costs, especially for the girl in high school.'

Some people also mentioned that difficult home environments also affect girls' and boys' educational performance.

'There is no suitable environment to study due to violence at home.'

'There is no place to study at home as it is very small.'

These economic problems have affected both adolescent girls' and boys' educational experiences, although because girls cannot work outside the home, they are more likely than 
boys to remain in school. However, girls are at risk of early marriage because of the lack of money to continue their education and their inability to work outside the home. Early marriage was raised as a risk by $17 \%$ of the adult women respondents and by the focus group of adolescent girls.

'Girls are more exposed to early marriage.'

'The family intends to marry off the daughter after she finishes high school, as they can't afford to send her to university.'

'I don't intend to marry off my daughters before age 18, so that they can finish their schooling.'

\subsubsection{Livelihoods opportunities for adolescent girls and support needed}

Despite the cultural restrictions on adolescent girls working outside the home, a number of permissible livelihoods opportunities were identified for older adolescent girls (16-18 years old). In ordering of frequency, the opportunities mentioned most often by respondents are:

- Embroidery, sewing, crochet and dressmaking

- Handmade crafts, decorations and accessories, including painting, flower arranging and woodcarving

- Food processing and making food products, including cheese, dairy and maftoul (grain)

- Baking pastries, cakes, sweets and bread

- Hairdressing, working in a salon, training in hairdressing

Other responses mentioned by multiple people are: poultry and agriculture, online/e-marketing, trade, fashion design, education and tutoring, making cleaning equipment and products, and dancing in a Dabke (traditional) band.

The focus group of adolescent girls were most interested in handmade crafts, embroidery, Dabke dance, online marketing, and making sweets and pastries.

The main type of support that would be needed for adolescent girls to pursue new livelihoods opportunities is training, including training courses and workshops. Most respondents mentioned multiple types of support needs. After training, the most frequently mentioned needs are capital or financial support, a safe place to work, psychological or moral support, and family and community support (see Figure 13). Some suggested that centres/organizations are needed to help support youth's talents and to provide training and protection. 
Figure 13. Support needed by adolescent girls for new livelihoods (frequency)

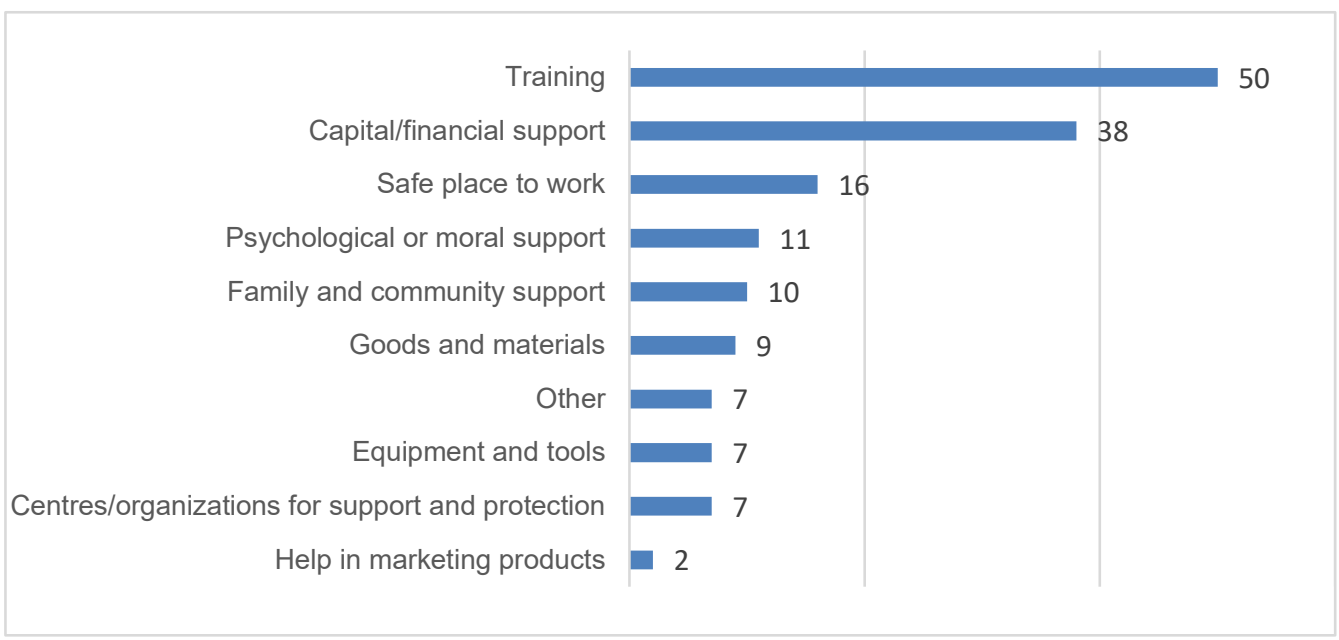

The focus group of adolescent girls identified the need for psychological support and encouragement by family, tools and materials that would be needed for the work, and training.

\subsubsection{Threats and risks from new livelihoods opportunities for adolescent girls}

The large majority of women and adolescent girls that participated in FGDs said there are potential risks for adolescent girls in starting livelihoods activities (see Figure 14).

Out of those who said there are potential risks, the most frequently identified risk is sexual harassment, followed by domestic violence or threats from family, and verbal or physical violence from any source. The full list of potential risks is shown in Figure 15. Most respondents mentioned more than one type of potential risk.

Some types of exposure to harm from livelihoods strategies include physical danger from using sharp tools and danger of fires during food processing. Some said that going to markets is dangerous for girls, and they would be dealing with untrusted people or organizations. Concerns over the limited number of hours with electricity available and working long hours for little profit are included under failure of the business.

Figure 14. Are there risks for adolescent girls in conducting livelihoods activities?

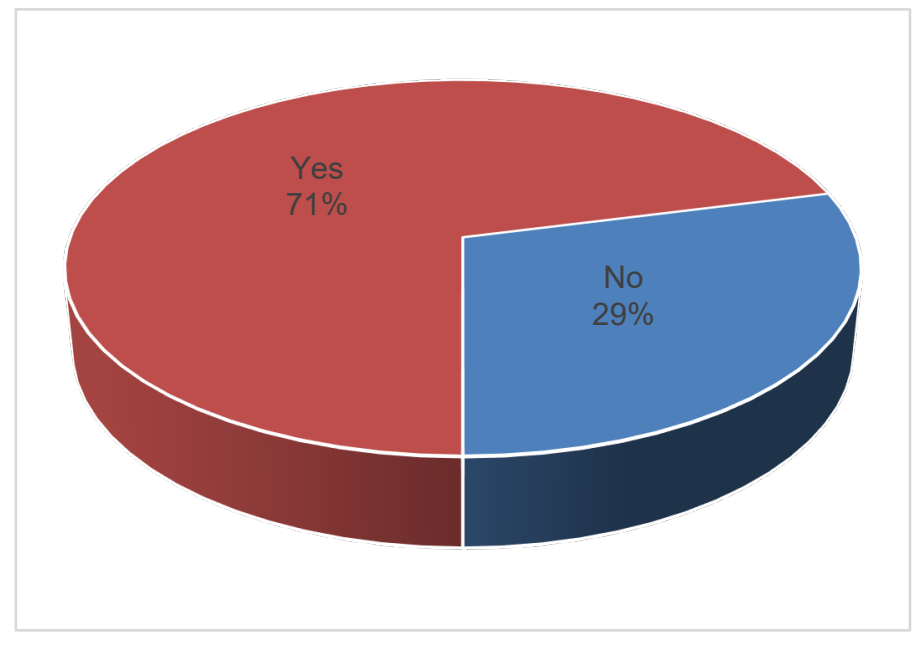


Figure 15. Potential risks for adolescent girls from new livelihoods opportunities

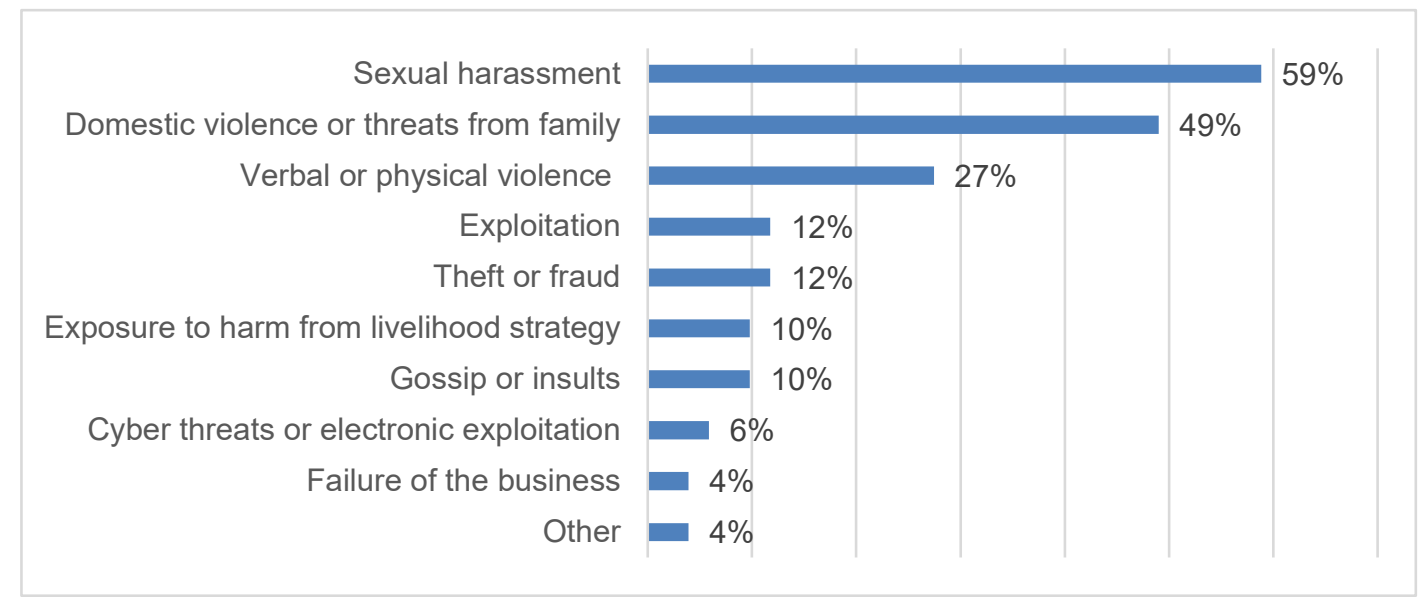

Participants in the adolescent girls' focus group were most concerned about verbal violence, kidnapping, sexual harassment, the threat of pictures shared online as a form of cyber violence, domestic violence, and discrimination between boys and girls.

\subsection{ADOLESCENT BOYS}

\subsubsection{Adolescent boys' participation in livelihoods and the impact on their education}

About $27 \%$ of respondents said that boys' participation in livelihoods has a negative impact on their education. Boys are much more likely than girls to leave school in order to earn income for their family, because (as discussed in the previous section) girls are not seen as able to work outside the home for income.

'My eldest son has left school to look for work to help me support the family.'

'The family pulled our son from school to learn a vocation to help earn a living for the family.'

'We send our son to sell ice cream and nuts at the market.'

There was no mention of boys being involved in or affected by other risky coping strategies that affect girls: no one mentioned boys engaging in sex for money or early marriage.

However, boys are affected by the same financial constraints affecting girls' households: lack of income to meet educational costs and school expenses such as uniforms, transportation, etc. Boys are more likely than girls to be removed from school when money is scarce, since they can work to contribute to the household's income.

'I couldn't enrol my son in kindergarten, which affected his educational level at school later.'

'I had to pull my son out of school and can't provide school needs for my other sons.' 
Boys are also affected by the home environment, such as violence at home or crowded conditions.

\subsubsection{Livelihoods opportunities for adolescent boys and support needed}

A number of permissible livelihoods opportunities were identified for older adolescent boys. Those mentioned most often by respondents, in order of frequency, are:

- Poultry rearing, egg selling or rabbit rearing

- Agriculture (including working on farms)

- Small retail or trade, including working in shops or the market

- Sewing

- Construction and casual labour

- Industry or factory work

- Food selling, such as hot beverages or popular foods

- Working in car mechanic shops

- Skilled trades like carpentry, plumbing, electrician or blacksmithing

- Technology-related fields like mobile phone repair, internet cafés, online work such as design

Other responses mentioned by multiple people include: transportation (including working as a taxi driver), distribution of goods, fishing and working in sports centres.

Participants in the adolescent boys' focus group were most interested in working in a bakery, working in an internet café, small retail, selling vegetables, and selling second-hand clothes.

The main type of support that would be needed for adolescent boys to pursue new livelihoods opportunities is capital or financial support, followed closely by training, including vocational training. Many respondents mentioned multiple types of support needs. The most frequently mentioned types of support are psychological or moral support (including building selfconfidence), a space to work, and work opportunities (see Figure 16). Equipment and tools, goods and materials, and other needs such as support from organizations, and organizing groups of boys to work together, were also identified.

Adolescent boys in the focus group identified the need for training courses, vocational training, capital, and work opportunities in particular. 
Figure 16. Support needed by adolescent boys for new livelihoods (frequency)

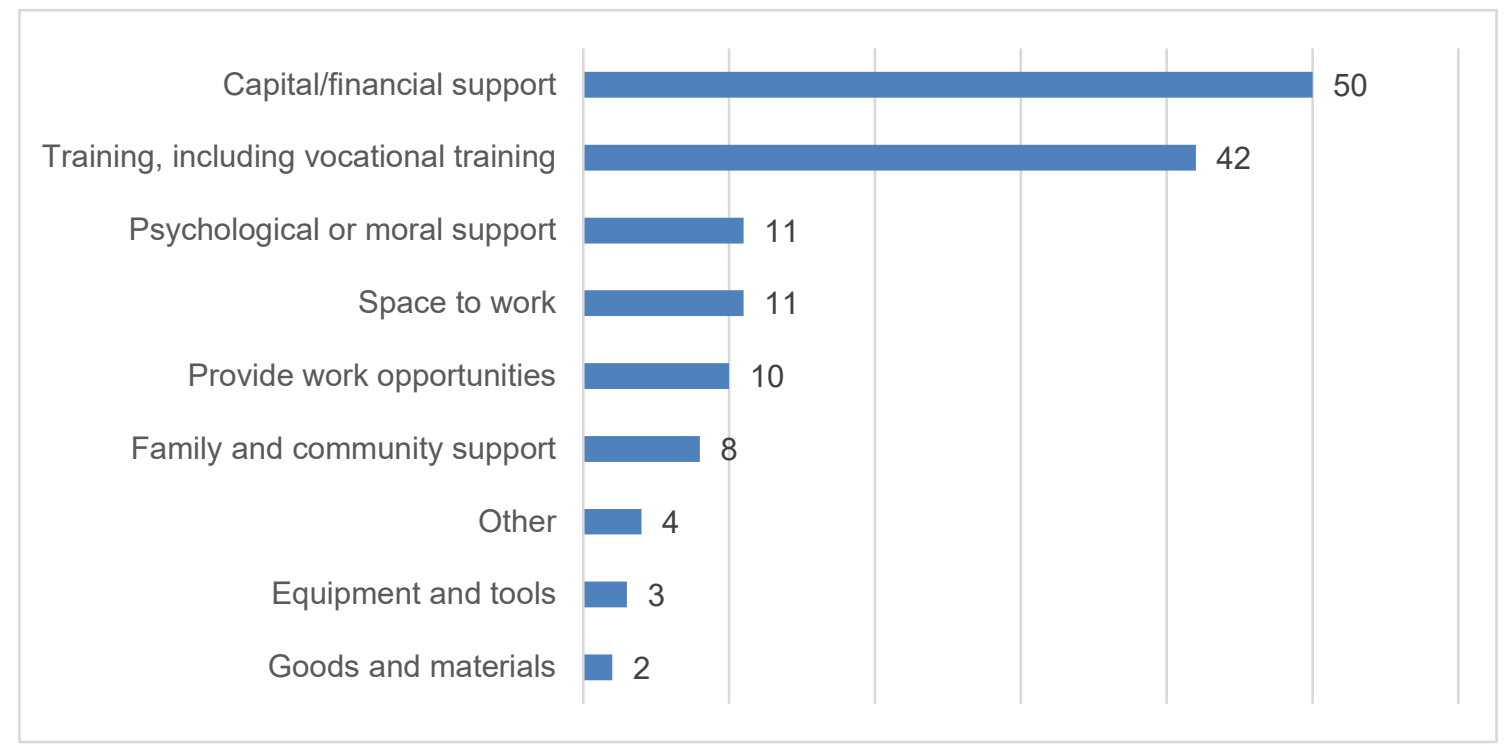

\subsubsection{Threats and risks from new livelihoods opportunities for adolescent boys}

The large majority of women and adolescent girls and boys interviewed say there are potential risks for adolescent boys in starting livelihoods activities (see Figure 17).

Out of those who said there are potential risks, the most frequently identified risk is verbal or physical abuse or the threat of this abuse, followed by theft or fraud, sexual harassment, and exploitation. The full list of potential risks is shown in Figure 18. Most respondents mentioned more than one type of potential risk.

Some types of risks that were identified for adolescent boys were not raised for women or for adolescent girls, including recruitment by Israel as a spy, negative peer influences and exposure to addiction or drugs. Other types of risks mentioned include electronic/cyber exploitation and government fines.

Figure 17. Are there risks for adolescent boys in conducting livelihoods activities?

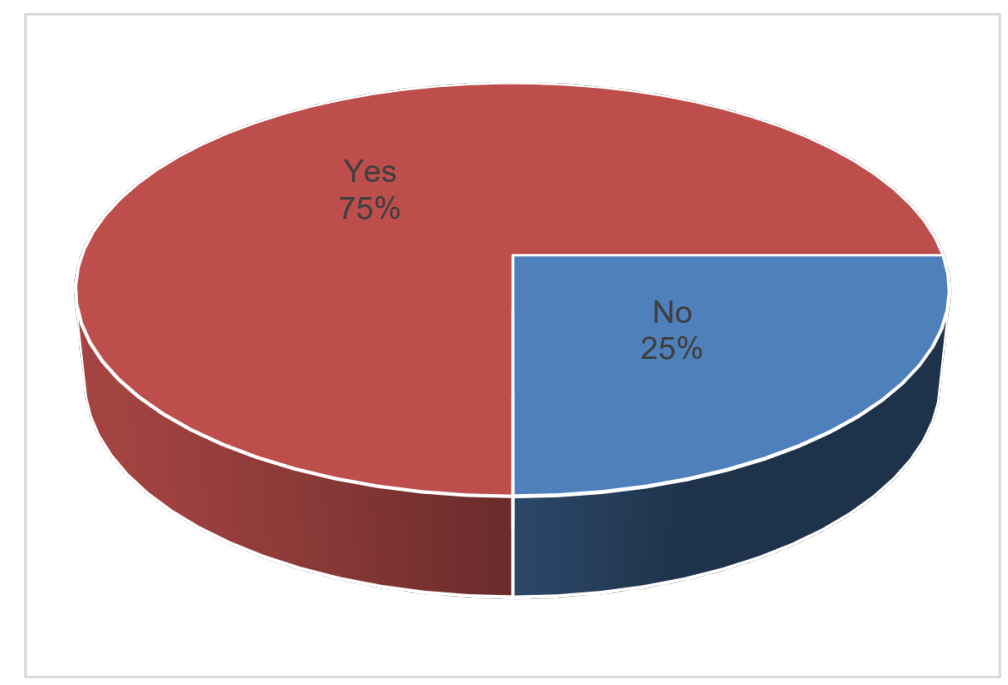


Figure 18. Potential risks for adolescent boys from new livelihoods opportunities

Verbal and physical abuse, or threats of these

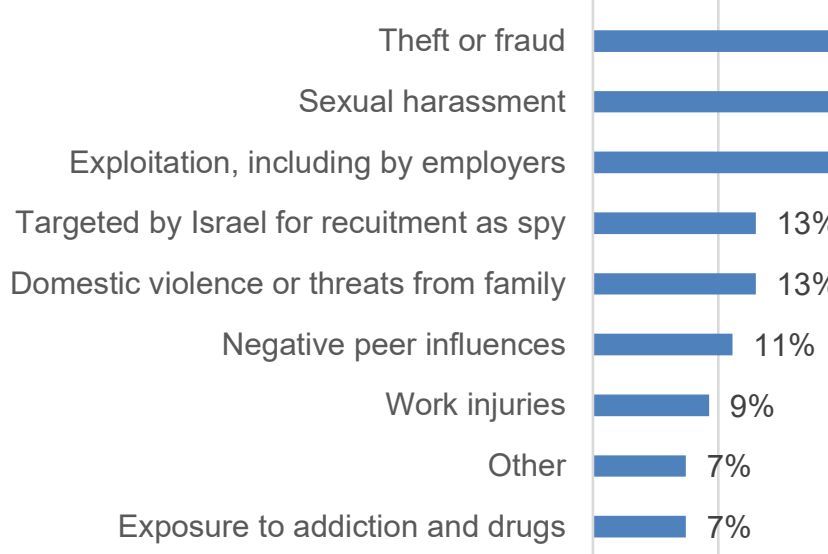

Although risks related to work injuries or working in a militarized/conflict environment were not identified by women and girls, participants of the adolescent boys' focus group were most concerned about these types of risks: they mentioned work hazards, dangers when working in a border area (such as the risk of getting shot if working as a paramedic) and the risk posed by explosive remnants of war (ERWs) when looking for metal scraps. 


\section{RECOMMENDATIONS FOR PREVENTION AND MITIGATION STRATEGIES}

As the findings of this analysis show, there are significant needs related to livelihoods - and significant risks. For women, adolescent girls and adolescent boys, $71-76 \%$ of those surveyed agreed that there are risks associated with pursuing livelihoods strategies in Gaza, as shown in the respective sections in this report.

Below is a consolidated list of the risks identified by the three groups, and potential prevention and mitigation strategies. The potential strategies were primarily identified by respondents through the interviews and focus groups, and some additional strategies were identified by staff of Oxfam as a result of this analysis.

Not all prevention and mitigation strategies will be feasible for Oxfam and partners to undertake, though Oxfam can play a positive role in contributing to most of them.

Finally, Oxfam must ensure that guidelines and minimum requirements for GBV prevention and mitigation are incorporated into all emergency food security and livelihoods programmes. ${ }^{20}$

Table 1. Risks related to livelihoods and potential mitigation strategies.

\begin{tabular}{|c|c|c|c|}
\hline Risk & Cohort & $\begin{array}{l}\text { Potential } \\
\text { prevention and } \\
\text { mitigation } \\
\text { strategies }\end{array}$ & $\begin{array}{l}\text { Can it be } \\
\text { addressed by } \\
\text { Oxfam and } \\
\text { partners? }\end{array}$ \\
\hline \multicolumn{4}{|l|}{ All } \\
\hline $\begin{array}{l}\text { Increased GBV and } \\
\text { other forms of violence } \\
\text { due to conflict and the } \\
\text { blockade } \\
\text { Increased survival sex } \\
\text { and early marriage due } \\
\text { to the conflict and the } \\
\text { blockade }\end{array}$ & $\begin{array}{l}\text { All women } \\
\text { survivors of GBV, } \\
\text { adolescent girls } \\
\text { and adolescent } \\
\text { boys } \\
\text { All women } \\
\text { survivors of GBV } \\
\text { and adolescent } \\
\text { girls }\end{array}$ & $\begin{array}{l}\text { Advocacy for } \\
\text { solution and end to } \\
\text { the blockade }\end{array}$ & $\begin{array}{l}\text { Oxfam can't end } \\
\text { the crisis, but can } \\
\text { use the results of } \\
\text { this analysis in } \\
\text { advocacy } \\
\text { messages to show } \\
\text { impact on civilians }\end{array}$ \\
\hline $\begin{array}{l}\text { IPV and domestic } \\
\text { violence (mostly in the } \\
\text { private domain of family) }\end{array}$ & $\begin{array}{l}\text { All women } \\
\text { survivors of GBV, } \\
\text { adolescent girls } \\
\text { and adolescent } \\
\text { boys }\end{array}$ & $\begin{array}{l}\text { Support } 21 \text { to } \\
\text { women's livelihoods } \\
\text { Support to men's } \\
\text { livelihoods } \\
\text { Involve male family } \\
\text { members in the } \\
\text { business if safe for } \\
\text { and desired by the } \\
\text { woman/girl }\end{array}$ & $\begin{array}{l}\text { Yes } \\
\text { Yes }\end{array}$ \\
\hline
\end{tabular}




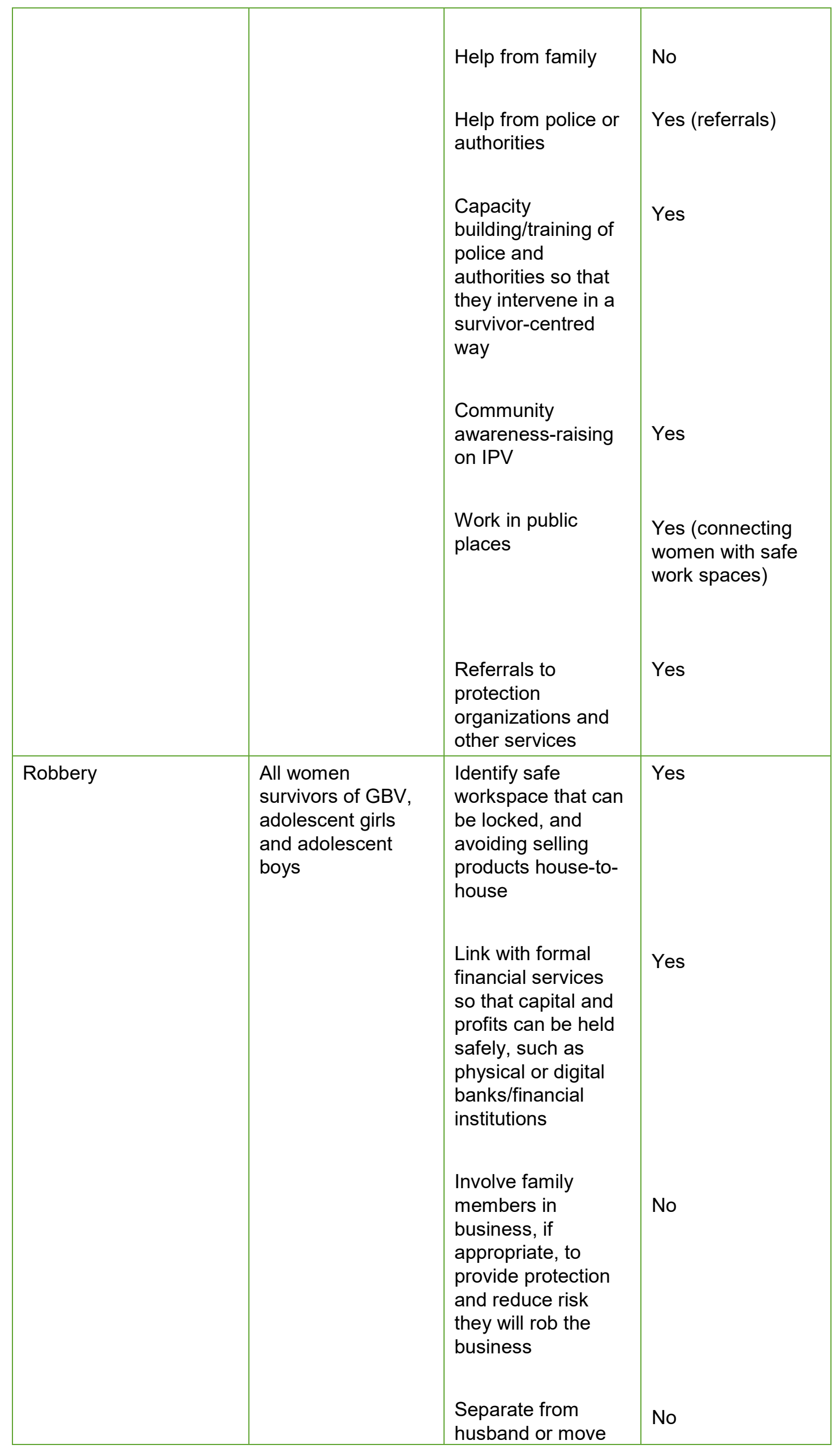




\begin{tabular}{|c|c|c|c|}
\hline & & $\begin{array}{l}\text { away from other } \\
\text { family members } \\
\text { Install security } \\
\text { cameras } \\
\text { Insurance for } \\
\text { equipment }\end{array}$ & $\begin{array}{l}\text { Maybe } \\
\text { Oxfam can provide } \\
\text { information }\end{array}$ \\
\hline $\begin{array}{l}\text { Fraud and exploitation } \\
\text { by traders or employers }\end{array}$ & $\begin{array}{l}\text { All women } \\
\text { survivors of GBV, } \\
\text { adolescent girls } \\
\text { and adolescent } \\
\text { boys }\end{array}$ & $\begin{array}{l}\text { Training in } \\
\text { documentation of } \\
\text { transactions and } \\
\text { invoicing } \\
\text { Ensure safe } \\
\text { methods of } \\
\text { reporting to } \\
\text { authorities if } \\
\text { needed } \\
\text { Build personal } \\
\text { qualities, including } \\
\text { confidence, and } \\
\text { keep self-interest in } \\
\text { mind to reduce } \\
\text { being targeted by } \\
\text { friends/neighbours/ } \\
\text { relatives } \\
\text { Learn how to } \\
\text { negotiate and get } \\
\text { competitive prices } \\
\text { from traders }\end{array}$ & Yes \\
\hline $\begin{array}{l}\text { Sexual harassment, } \\
\text { robbery, } \\
\text { assault/violence and } \\
\text { other forms of GBV }\end{array}$ & $\begin{array}{l}\text { All groups who } \\
\text { have to travel } \\
\text { outside of their } \\
\text { area of living for } \\
\text { their livelihoods } \\
\text { strategy or to their } \\
\text { work location }\end{array}$ & $\begin{array}{l}\text { Utilize } \\
\text { transportation } \\
\text { (beyond providing } \\
\text { cash, providing } \\
\text { protected means of } \\
\text { transport for these } \\
\text { women and girls to } \\
\text { get to their work } \\
\text { locations) } \\
\\
\text { Travel in groups, in } \\
\text { daylight, seek } \\
\text { protection from } \\
\text { police or security } \\
\text { officers and/or be } \\
\text { accompanied by }\end{array}$ & $\begin{array}{l}\text { Yes, could be } \\
\text { considered in } \\
\text { interventions } \\
\text { Oxfam can provide } \\
\text { information and } \\
\text { referrals }\end{array}$ \\
\hline
\end{tabular}




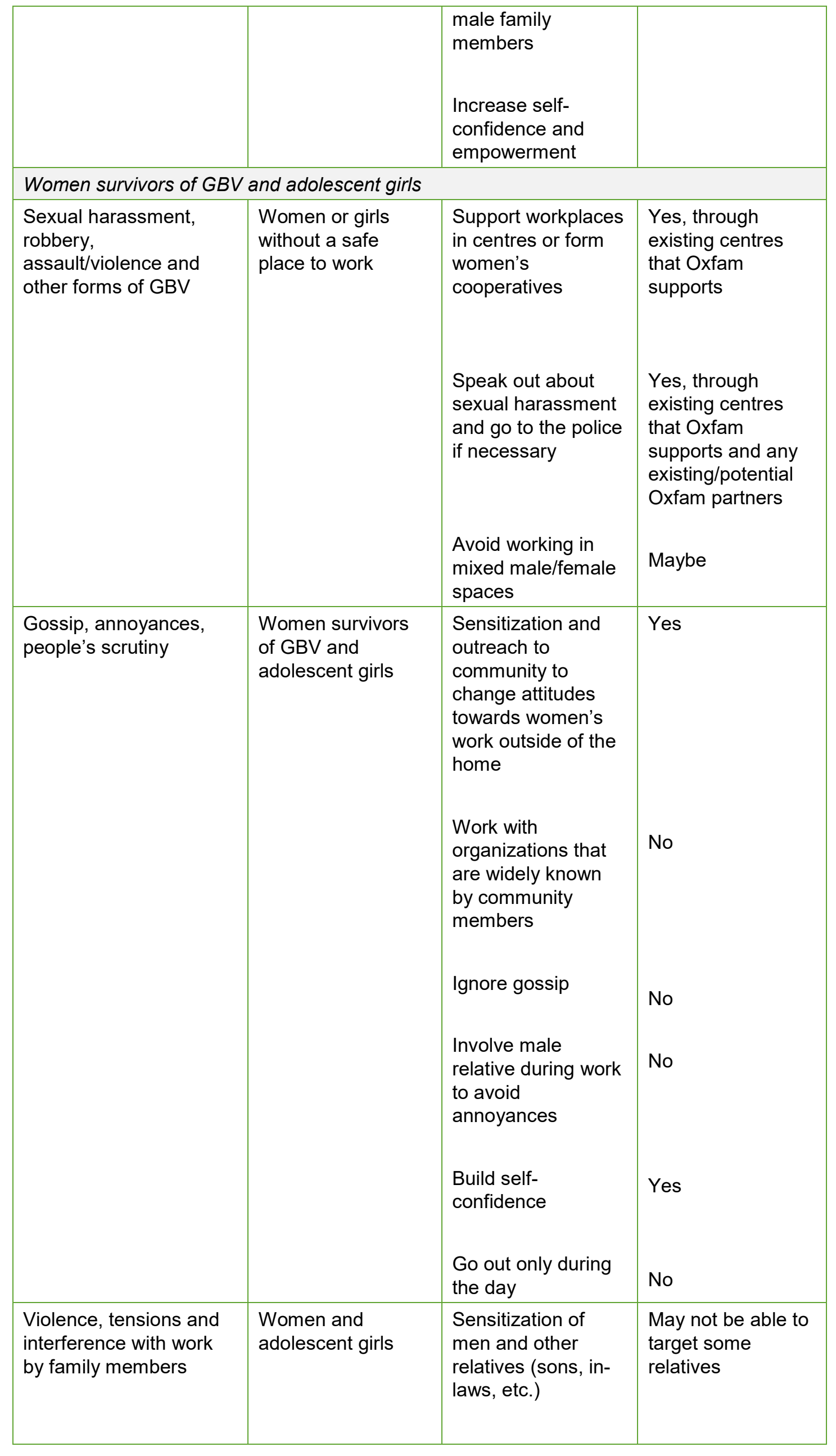




\begin{tabular}{|c|c|c|c|}
\hline & & $\begin{array}{l}\text { Referrals to legal } \\
\text { protection and other } \\
\text { services for women } \\
\text { Referrals to } \\
\text { counselling } \\
\text { services if required } \\
\text { Give family part of } \\
\text { profits } \\
\text { Keep work and } \\
\text { profits in a safe } \\
\text { place } \\
\text { Reach greater } \\
\text { understanding with } \\
\text { in-laws and other } \\
\text { family members } \\
\text { Go to community } \\
\text { leaders to solve } \\
\text { family disputes }\end{array}$ & $\begin{array}{l}\text { Yes } \\
\text { No } \\
\text { Yes } \\
\text { No } \\
\text { No }\end{array}$ \\
\hline $\begin{array}{l}\text { Forced into sex for } \\
\text { money or survival sex }\end{array}$ & $\begin{array}{l}\text { Women and } \\
\text { adolescent girls }\end{array}$ & $\begin{array}{l}\text { Support to dignified } \\
\text { livelihoods for } \\
\text { women and girls } \\
\text { Support to food and } \\
\text { basic needs of } \\
\text { households } \\
\text { Support to men's } \\
\text { livelihoods } \\
\text { Support access to } \\
\text { safe reporting to } \\
\text { police or authorities } \\
\text { Referrals to } \\
\text { counselling, clinics } \\
\text { and reproductive } \\
\text { health services } \\
\text { Sensitization } \\
\text { around GBV and } \\
\text { women's rights }\end{array}$ & $\begin{array}{l}\text { Yes } \\
\text { Yes } \\
\text { Yes } \\
\text { Yes } \\
\text { Yes } \\
\text { Yes }\end{array}$ \\
\hline \multicolumn{4}{|l|}{ Women survivors of GBV } \\
\hline $\begin{array}{l}\text { Inability to meet food } \\
\text { and other basic needs }\end{array}$ & $\begin{array}{l}\text { Women who rely } \\
\text { on assistance and } \\
\text { others without }\end{array}$ & $\begin{array}{l}\text { Provide vouchers or } \\
\text { cash for meeting } \\
\text { food and basic } \\
\text { needs while }\end{array}$ & Yes \\
\hline
\end{tabular}




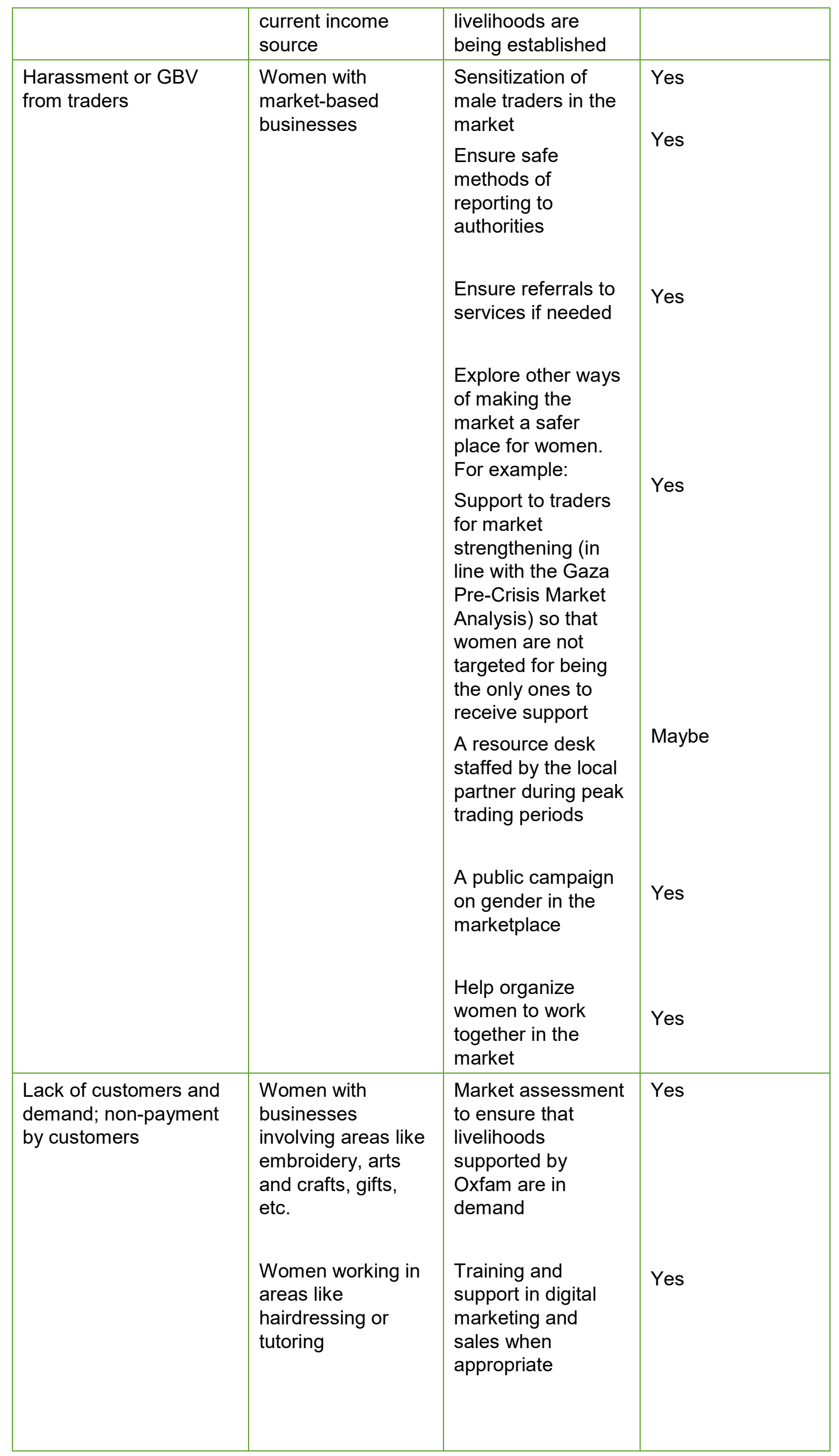




\begin{tabular}{|c|c|c|c|}
\hline & & $\begin{array}{l}\text { Collecting payment } \\
\text { from customers } \\
\text { upfront } \\
\text { Select good } \\
\text { business location to } \\
\text { attract customers } \\
\text { Good advertising } \\
\text { and marketing to } \\
\text { attract customers }\end{array}$ & $\begin{array}{l}\text { No } \\
\text { Yes } \\
\text { Oxfam can provide } \\
\text { training }\end{array}$ \\
\hline $\begin{array}{l}\text { Poor business } \\
\text { management }\end{array}$ & $\begin{array}{l}\text { Women with } \\
\text { market-based } \\
\text { businesses }\end{array}$ & $\begin{array}{l}\text { Provide training in } \\
\text { business } \\
\text { management } \\
\text { Ongoing support } \\
\text { and monitoring of } \\
\text { business } \\
\text { Set up mentoring } \\
\text { and links with more } \\
\text { experienced people } \\
\text { Provide appropriate } \\
\text { equipment and } \\
\text { technical } \\
\text { information }\end{array}$ & $\begin{array}{l}\text { Yes } \\
\text { Yes } \\
\text { Yes } \\
\text { Yes }\end{array}$ \\
\hline $\begin{array}{l}\text { Humiliation from having } \\
\text { to work }\end{array}$ & $\begin{array}{l}\text { Women entering } \\
\text { the work force }\end{array}$ & $\begin{array}{l}\text { Create networks of } \\
\text { women to connect } \\
\text { with and support } \\
\text { each other } \\
\text { Support dignified } \\
\text { livelihoods activities } \\
\text { Build self- } \\
\text { confidence of } \\
\text { women and girls } \\
\text { and change } \\
\text { attitudes to } \\
\text { women's work } \\
\text { Sensitize men and } \\
\text { boys to support a } \\
\text { change in attitudes } \\
\text { to women's work } \\
\text { Support from family } \\
\text { and community } \\
\text { members }\end{array}$ & $\begin{array}{l}\text { Yes } \\
\text { Yes } \\
\text { Yes } \\
\text { Yes } \\
\text { No }\end{array}$ \\
\hline
\end{tabular}




\begin{tabular}{|c|c|c|c|}
\hline Early marriage & $\begin{array}{l}\text { Girls from families } \\
\text { with economic } \\
\text { problems }\end{array}$ & $\begin{array}{l}\text { Support to } \\
\text { household's basic } \\
\text { needs } \\
\text { Support to } \\
\text { household } \\
\text { livelihoods to } \\
\text { increase income } \\
\text { Support to } \\
\text { adolescent girls' } \\
\text { vocational and } \\
\text { livelihood skills so } \\
\text { that they become } \\
\text { self-sufficient } \\
\text { Sensitization of } \\
\text { parents around } \\
\text { risks of early } \\
\text { marriage and rights } \\
\text { of the child } \\
\text { Referrals to support } \\
\text { services in } \\
\text { coordination with } \\
\text { schools and } \\
\text { educational support } \\
\text { centres } \\
\text { Awareness-raising } \\
\text { in schools }\end{array}$ & $\begin{array}{l}\text { Yes, or through } \\
\text { connection to other } \\
\text { organizations } \\
\text { working on this } \\
\text { Yes } \\
\text { Maybe }\end{array}$ \\
\hline \multicolumn{4}{|l|}{ Adolescent boys } \\
\hline $\begin{array}{l}\text { Exposure to drugs and } \\
\text { addiction }\end{array}$ & $\begin{array}{l}\text { Boys entering } \\
\text { workforce or certain } \\
\text { industries }\end{array}$ & $\begin{array}{l}\text { Organizations that } \\
\text { support youth and } \\
\text { provide information } \\
\text { on the dangers of } \\
\text { drug use } \\
\text { Awareness-raising } \\
\text { for parents and } \\
\text { community on signs } \\
\text { and risks of drug } \\
\text { abuse } \\
\text { Awareness-raising } \\
\text { through social } \\
\text { media }\end{array}$ & $\begin{array}{l}\text { Oxfam can liaise } \\
\text { with these } \\
\text { organizations } \\
\text { and/or integrate } \\
\text { into Saving Lives } \\
\text { activities }\end{array}$ \\
\hline $\begin{array}{l}\text { Coercion into spying for } \\
\text { opposing forces }\end{array}$ & $\begin{array}{l}\text { Boys without other } \\
\text { livelihoods options } \\
\text { or means of } \\
\text { support }\end{array}$ & $\begin{array}{l}\text { Awareness-raising } \\
\text { on dangers }\end{array}$ & Maybe \\
\hline
\end{tabular}




\begin{tabular}{|l|l|l|}
\hline & $\begin{array}{l}\text { Seek help of } \\
\text { internal security } \\
\text { forces }\end{array}$ & No \\
& $\begin{array}{l}\text { Provide access to } \\
\text { vocational and } \\
\text { other livelihoods } \\
\text { training }\end{array}$ & Yes \\
\hline
\end{tabular}


1 The CLARA methodology uses one point in time as comparison point (before/ after or since that point .....) and it is agreed upon within the research team based on some factors: we agreed on the beginning of PA salaries cuts crisis starting April,2017 as it was reportedly a starting point for further deterioration on multiple levels

2 Women's Refugee Commission (2016) CLARA: Cohort Livelihoods and Risk Analysis Guidance and Tools, https://www.womensrefugeecommission.org/issues/livelihoods/research-and-resources/1231clara-tool

3 This summary is informed by other recent Oxfam analyses in Gaza, including: Oxfam (2018) The Crisis is Now: A Pre-Crisis Market Analysis of Credit, Mattresses and Drinking Water in the Gaza Strip, https://www.emma-toolkit.org/report/crisis-now-pre-crisis-market-analysis-credit-mattresses-anddrinking-water-gaza-strip; and Oxfam (2019) Participatory Vulnerability Analysis in the North of the Gaza Strip, https://policy-practice.oxfam.org.uk/publications/participatory-vulnerability-analysis-in-thenorth-of-the-gaza-strip-620627

${ }^{4}$ World Bank (2018) Economic Monitoring Report to the Ad Hoc Liaison Committee, http://documents.worldbank.org/curated/en/413851537281565349/pdf/129986-REVISED-World-BankSept-2018-AHLC-Report-final.pdf

5 Oxfam (2018) The Crisis is Now, op. cit.

${ }^{6}$ Gisha - Legal Center for Freedom of Movement. 'Unemployment rate in Gaza reaches new record-high of 52 percent in 2018', https://gisha.org/updates/9840.

7 Ibid.

${ }^{8}$ Palestinian Central Bureau of Statistics (PCBS), http://www.pcbs.gov.ps.

9 Palestinian Food Security Sector Q2-2018 update, https://fscluster.org/sites/default/files/documents/fss wbgs brief 2018-q2.pdf

10 United Nations Country Team in the occupied Palestinian territory (2017) Gaza Ten Years Later, https://www.un.org/unispal/document/gaza-ten-years-later-un-country-team-in-the-occupiedpalestinian-territory-report/

11 Oxfam (2019) Participatory Vulnerability Analysis in the North of the Gaza Strip, https://policypractice.oxfam.org.uk/publications/participatory-vulnerability-analysis-in-the-north-of-the-gaza-strip$\underline{620627}$

12 United Nations Country Team in the occupied Palestinian territory (2017) Gaza Ten Years Later. Op. cit.

${ }^{13}$ Food Security Sector (2018). Socio-Economic Food Security Survey: 2018 Preliminary Results, https://fscluster.org/sites/default/files/documents/sefsec 2018 food security analysis preliminary results.pdf

14 UNFPA (2017) The Humanitarian Impact of Gaza's Electricity and Fuel Crisis on Gender-based Violence and services, https://palestine.unfpa.org/sites/default/files/pubpdf/Humanitarian\%20Impact $\% 20$ of $\% 20$ Gaza $\% 27 \mathrm{~s} \% 20$ Electricity $\% 20$ and $\% 20$ Fuel $\% 20$ Crisis $\% 20$ on $\% 2$ 0Gender-based $\% 20$ Violence $\% 20$ and $\% 20$ services $\% 20-\% 2029 \% 20$ May $\% 202017$.pdf

15 lbid.

16 UN Women (2017) Navigating Through Shattered Paths: NGO Service Providers and Women Survivors of Gender-Based Violence, An Assessment of GBV Services in Gaza, http://www.globalprotectioncluster.org/_assets/files/navigating-through-shattered-paths-ngo-serviceproviders-and-women-survivors-of-gender-based-violence-gbv-research-2017.pdf

17 United Nations Country Team in the occupied Palestinian territory (2017) Gaza Ten Years Later. Op. cit.

18 Ibid.

19 Operation cast lead, 2008-2009 which caused 1444 fatalities

20 Inter-Agency Standing Committee (2015) Guidelines for Integrating Gender-Based Violence Interventions in Humanitarian Action: Reducing risk, promoting resilience and aiding recovery, https://gbvguidelines.org/en/; Women's Refugee Commission: Checklist for Integrating Protection/GBV Mitigation into Livelihood Programs, https://www.womensrefugeecommission.org/images/zdocs/integrating protection checklist.pdf

21 Support to women's (or men's) livelihoods could include financial or capital support, access to goods or materials, equipment or tools, capacity building and training, business planning, and more as appropriate. 


\section{ACKNOWLEDGEMENTS}

This report was prepared by Emily Farr, Emergency Food Security and Vulnerable Livelihoods (EFSVL) Advisor in Oxfam's Global Humanitarian Team. It was conducted as part of a project designed and implemented by Oxfam and partner MA'AN Development Center to address food insecurity and protection needs in the protracted emergency taking place in North Gaza. The author also wish to thank the Oxfam Team and partner staff from the following NGOs who supported and facilitated data collection, outreach to surveyed people and the adaptation of tools, and in particular Najla Al-Shawa (FSL manager) - Fidaa Al-Araj (Gender justice and protection officer), AlHasan Swairjo (Saving Lives MEAL Officer). It was made possible by funding from Directorate-general Development Cooperation and Humanitarian Aid (DGD). 


\section{ANNEX: QUESTIONNAIRE}

1A. What activities are you doing now to meet your basic needs and earn a living?

1B. Notes about livelihood and source of income

2A. Was your livelihood affected? If so, by what event?

2B. If yes, how was your livelihood affected?

$3 \mathrm{~A}$. Are there any livelihoods activities you do now that make you feel vulnerable/unsafe/less safe?

3B. If yes, what are the risks/threats?

4A. Are there any livelihood activities that you did before the crisis that made you feel vulnerable/unsafe/less safe?

4B. Did the risk increase after 'the crisis'?

4BA. If yes, how?

$5 \mathrm{~A}$. What are the strategies you are using to feel safer now when doing these activities?

5B. What are the serious actions you are using to feel safer now, if any?

$6 \mathrm{~A}$. What are the strategies you used to feel safer before 'the crisis' when doing these activities?

6B. What are the series actions you used before 'the crisis' to feel safer, if any?

1. Have there been any positive or negative changes to your livelihood since 'the crisis'?

8A. How would you get back to generating income/improve your livelihood?

$8 \mathrm{~B}$. What support/inputs do you need to make this happen?

[Questions 9A-9C from the original tool are for host community members and were skipped]

10. What risks/threats might you face receiving this support?

11. How could these risks/threats be managed?

12. What kinds of livelihoods activities can be done by women?

13. What might be threats to women while doing these activities?

How could these risks for women be managed?

15A. Does participating in livelihoods activities now impact your children's education? 15AA. Notes

15B. Different for girls and boys?

15BA. If yes, why?

16A. Did participating in livelihoods activities before 'the crisis' impact your children's education?

16AA. Notes

16B. Different for girls and boys?

16BA. If yes, why?

17A. Has access to education changed since 'the crisis'? 
17B. Differently for girls and boys?

17BA. If yes, why?

17BB. Girls and boys of different ages?

17BC. If yes, why?

18A. What kinds of livelihoods activities can be done by older adolescent girls?

18B. What support is needed by older adolescent girls?

19. What might be threats to girls while doing these activities?

20. How could these risks for girls be managed?

21A. What kinds of livelihoods activities can be done by older adolescent boys?

21B. What support is needed by older adolescent boys?

22. What might be threats to boys while doing these activities?

23. How could these risks for boys be managed?

24A. To your knowledge, do members of your community ever engage in sex work, commercial sex, or sell sex, as a means of livelihood?

24AA. Notes

25. Observations and notes about the case in general 


\section{OXFAM RESEARCH REPORTS}

Oxfam Research Reports are written to share research results, to contribute to public debate and to invite feedback on development and humanitarian policy and practice. They do not necessarily reflect Oxfam policy positions. The views expressed are those of the author and not necessarily those of Oxfam.

For more information, or to comment on this report, email Fidaa.alaraj@oxfam.org and Emily.farr@oxfam.org

(c) Oxfam International January 2020

This publication is copyright but the text may be used free of charge for the purposes of advocacy, campaigning, education, and research, provided that the source is acknowledged in full. The copyright holder requests that all such use be registered with them for impact assessment purposes. For copying in any other circumstances, or for re-use in other publications, or for translation or adaptation, permission must be secured and a fee may be charged. Email policyandpractice@oxfam.org.uk

The information in this publication is correct at the time of going to press.

Published by Oxfam GB for Oxfam International under ISBN 978-1-78748-528-0 in January 2020.

Oxfam GB, Oxfam House, John Smith Drive, Cowley, Oxford, OX4 2JY, UK.

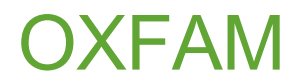

Oxfam is an international confederation of 20 organizations networked together in more than 90 countries, as part of a global movement for change, to build a future free from the injustice of poverty. Please write to any of the agencies for further information, or visit www.oxfam.org

Oxfam America (www.oxfamamerica.org)

Oxfam Australia (www.oxfam.org.au)

Oxfam-in-Belgium (www.oxfamsol.be)

Oxfam Brasil (www.oxfam.org.br)

Oxfam Canada (www.oxfam.ca)

Oxfam France (www.oxfamfrance.org)

Oxfam Germany (www.oxfam.de)

Oxfam GB (www.oxfam.org.uk)

Oxfam Hong Kong (www.oxfam.org.hk)

Oxfam IBIS (Denmark) (www.oxfamibis.dk)
Oxfam India (www.oxfamindia.org)

Oxfam Intermón (Spain) (www.oxfamintermon.org)

Oxfam Ireland (www.oxfamireland.org)

Oxfam Italy (www.oxfamitalia.org)

Oxfam Mexico (www.oxfammexico.org)

Oxfam New Zealand (www.oxfam.org.nz)

Oxfam Novib (Netherlands) (www.oxfamnovib.nl)

Oxfam Québec (www.oxfam.qc.ca)

Oxfam South Africa (www.oxfam.org.za)

Observer: KEDV (Oxfam Turkey) 